\title{
Adiposity and fat distribution in relation to inflammation and oxidative stress in a relatively lean population of Chinese women
}

\author{
Sheng-Hui $\mathrm{Wu}^{\mathrm{a}}$, Xiao-Ou Shu ${ }^{\mathrm{a}}$, Wong-Ho Chow ${ }^{\mathrm{b}}$, Yong-Bing Xiang ${ }^{\mathrm{c}}$, Xianglan Zhang ${ }^{\mathrm{a}}$, Qiuyin Cai ${ }^{\mathrm{a}}$, \\ Hong-Lan Li ${ }^{\mathrm{c}}$, Ginger Milne ${ }^{\mathrm{d}}$, Wanqing Wen ${ }^{\mathrm{a}}$, Bu-Tian Ji ${ }^{\mathrm{b}}$, Nathaniel Rothman ${ }^{\mathrm{b}}$, Yu-Tang $\mathrm{Gao}^{\mathrm{c}}$, \\ Wei Zheng ${ }^{\mathrm{a}}$ and Gong Yang ${ }^{\mathrm{a}, *}$ \\ ${ }^{a}$ Division of Epidemiology, Department of Medicine, Vanderbilt University Medical Center, Nashville, TN, USA \\ ${ }^{\mathrm{b}}$ Division of Cancer Epidemiology and Genetics, National Cancer Institute, NIH, DHHS, Bethesda, MD, USA \\ ${ }^{\mathrm{c}}$ Shanghai Cancer Institute, Shanghai, China \\ ${ }^{\mathrm{d}}$ Division of Clinical Pharmacology, Department of Medicine, Vanderbilt University Medical Center, Nashville, \\ TN, USA
}

\begin{abstract}
.
OBJECTIVES: This study evaluated associations of various anthropometric measures of adiposity with a panel of inflammatory and oxidative stress markers in a relatively lean population of Chinese women.

METHODS: This analysis included 1,005 Chinese women aged 40-70 years. Plasma concentrations of inflammatory and oxidative stress markers were measured. Anthropometric measurements were taken by trained interviewers.

RESULTS: Body mass index (BMI), waist circumference (WC), and waist-to-height ratio (WHtR) were all positively and linearly associated with the inflammatory markers, CRP, TNF- $\alpha$, soluble TNF-receptor 1 (sTNF-R1), and IL-6. A significant positive association of these measures of adiposity with the oxidative stress marker $\mathrm{F}_{2}$-IsoP-M, a metabolite of $\mathrm{F}_{2}$-IsoPs, but with not $\mathrm{F}_{2}$-IsoPs was found. Differences in biomarkers between extreme quartiles of anthropometric measurements varied widely, ranging from $9.7 \%$ for sTNF-R1 to $162.0 \%$ for CRP. For each specific biomarker, various anthropometric measurements exhibited similar ability to explain variations in the biomarker, with the biggest partial $r^{2}(11 \%)$ observed for CRP.

CONCLUSIONS: This study suggests that both general adiposity (measured by BMI) and central adiposity (measured by $\mathrm{WC}$ and $\mathrm{WHtR}$ ) are positively and similarly associated with various markers of inflammation and oxidative stress in relatively lean Chinese women. The metabolite $\mathrm{F}_{2}$-IsoP-M of $\mathrm{F}_{2}$-IsoPs may be a better marker of in vivo oxidative stress than its parent compounds.
\end{abstract}

Keywords: Adiposity, inflammation, oxidative stress, biomarker

\section{Introduction}

Obesity is now viewed as a low-grade inflammatory condition [1]. To date, investigations of obesity

${ }^{*}$ Corresponding author: Gong Yang, Division of Epidemiology, Department of Medicine, Vanderbilt University Medical Center, 2525 West End Avenue, Suite 600 (IMPH), Nashville, TN 372031738, USA. Tel.: +1 615936 0748; Fax: +1 615936 8291; E-mail: Gong.Yang@Vanderbilt.edu. and inflammation [2-7] and oxidative stress [8,9] have been conducted mainly in Western populations where overweight and obesity are highly prevalent. The relationship between general or central adiposity and inflammation and oxidative stress in a relatively lean population is not well characterized. Data on the effect of fat distribution on inflammation and oxidative stress are mixed [10-13], showing stronger associations with measures of central adiposity in some [10, $11]$, but not all studies $[12,13]$. In addition, many in- 
flammatory mediators have been found to be involved in obesity-related diseases. Most previous studies of obesity and inflammation have focused mainly on Creactive protein $(\mathrm{CRP})[3,5,6]$. It remains controversial which anthropometric measurements and inflammatory biomarkers are the most appropriate to describe the association of obesity and inflammation or oxidative stress.

The measurement of urinary $\mathrm{F}_{2}$-isoprostanes $\left(\mathrm{F}_{2}\right.$ IsoPs) is now well accepted as the most accurate and reliable biomarker of oxidative stress in vivo [14, 15]. Urine is considered an ideal biological material for the measurement of $\mathrm{F}_{2}$-IsoPs because, unlike plasma, urine does not have a high lipid content; therefore, there is less concern about artifactual generation of isoprostanes by lipid autoxidation during sampling and storage [16]. After $\beta$-oxdidation, $15-\mathrm{F}_{2 t^{-}}$ Isoprostane (15- $\mathrm{F}_{2 t}$-Isop), one of the major $\mathrm{F}_{2}$-IsoPs, is converted to 2,3-dinor-5,6-dihydro- $15-\mathrm{F}_{2 t}$ - IsoP $\left(\mathrm{F}_{2}\right.$ IsoP-M), which is not subject to renal production [17]. Our previous observations suggest that $\mathrm{F}_{2}$-IsoP-M may be a better marker of in vivo systemic oxidative stress than its parent compounds [18].

The present study evaluated associations of anthropometric measures of adiposity with a panel of inflammatory and oxidative stress markers and examined potential heterogeneity by measures of fat distribution among 1,005 middle-aged women in Shanghai, China, with a mean BMI of $24.6 \mathrm{~kg} / \mathrm{m}^{2}$.

\section{Methods and procedures}

\subsection{Study participants}

This cross-sectional analysis was conducted among 1,005 women originally selected for a nested casecontrol study of colorectal cancer among participants of the Shanghai Women's Health Study (SWHS), an ongoing, population-based, prospective cohort study. The design and methods of the SWHS have been described in depth elsewhere [19,20]. Briefly, at the baseline survey conducted between 1997 and 2000, 74,941 women aged 40-70 y from 7 typical urban communities of Shanghai were recruited (participation rate: $92.7 \%$ ). All women completed a detailed baseline survey that collected information on demographic characteristics, lifestyle and dietary habits, medical history, and other exposures. A detailed assessment of physical activity was obtained using a validated questionnaire [21]. The study was approved by the relevant institutional review boards for human research in both China and the United States. Written informed consent was obtained from all study participants.

\subsection{Anthropometry}

Participants were asked to wear light indoor clothing when they were measured for weight, height, and circumferences of the waist and hips by trained interviewers. The measurement was conducted uniformly according to a standard protocol. Waist circumference (WC) was measured at $2.5 \mathrm{~cm}$ above the umbilicus and hip circumference (HC) at the level of maximum width of the buttocks with the participant in a standing position. Circumferences and heights were measured to the nearest $0.1 \mathrm{~cm}$. Weight was measured to the nearest $0.1 \mathrm{~kg}$ using a digital weight scale that was calibrated every 6 months. All measurements were taken twice. A tolerance limit of $1 \mathrm{~kg}$ was set for the weight measurement and $1 \mathrm{~cm}$ for height and circumference measurements. A third measurement was taken if the difference between the first 2 measurements was greater than the tolerance limit. Using the average of the 2 closest measurements, waist-to-hip ratio (WHR; waist circumference divided by hip circumference), BMI (weight in kilograms divided by the square of height in meters), and waist-to-height ratio (WHtR; waist circumference divided by height in centimeters) were then calculated for the analysis.

\subsection{Dietary intake}

Habitual dietary intake data over the 12 months preceding the interview were collected during in-person interviews using a validated food-frequency questionnaire (FFQ) that included 77 food items/groups commonly consumed in Shanghai [19] to assess intake of dietary antioxidant-rich foods (such as fruits and vegetables) and antioxidant vitamins (such as vitamins $\mathrm{C}$ and $\mathrm{E}$ ). Nutrient consumption and total energy intake were calculated by summing the product of food intake and the nutrient content of the food item based on the 2002 Chinese Food Composition Tables [22].

\subsection{Biomarker measurement}

At study enrollment, $76 \%$ of cohort members donated baseline blood and urine samples; an additional $12 \%$ of cohort members donated a urine sample during the first follow-up survey (approximately 2 years later) $[19,20]$. After collection, samples were kept at 
$0-4{ }^{\circ} \mathrm{C}$ and processed within 6 hours. Immediately after processing, all samples were stored at $-70^{\circ} \mathrm{C}$ until laboratory analyses were conducted.

Cytokines and their receptors were measured by using Millipore's MILLIPLEX ${ }^{\circledR}$ MAP High Sensitivity Human Cytokine multiplex kit for IL-1 $\beta$, IL-6, and TNF- $\alpha$ and the MILLIPLEX ${ }^{\circledR}$ MAP Human Soluble Cytokine Receptor Panel multiplex kits for soluble IL-6 receptor (sIL-6R), soluble GP130 (sGP130, a regulator of IL-6/sIL-6R complex signaling), soluble TNF-R1 (sTNF-R1), and sTNF-R2. Assays were conducted in duplicate at the Hormone Assay and Analytical Services Core at Vanderbilt University, Nashville, USA, from 2009 to 2010, following relevant manufacturer's instructions. High-sensitivity CRP measurements were performed at Vanderbilt University Hospital's lipids lab using the $A C E^{\circledR}$ High Sensitivity CReactive Protein Reagent (ACI-22) for the first batch and the CRP (HS) Wide Range kit (Pointe Scientific, Canton, MI) for the second batch. Thus, we adjusted for batch in all analyses. The limits of detection were as follows: TNF- $\alpha, 0.05 \mathrm{pg} / \mathrm{mL}$; sTNF-R1, $9.6 \mathrm{pg} / \mathrm{mL}$; sTNF-R2, $16.9 \mathrm{pg} / \mathrm{mL}$; IL-1 $\beta, 0.06 \mathrm{pg} / \mathrm{mL}$; IL-6, $0.10 \mathrm{pg} / \mathrm{mL}$; sGP130, $7.2 \mathrm{pg} / \mathrm{mL}$; sIL-6R, $3.6 \mathrm{pg} / \mathrm{mL}$; and CRP, $0.1 \mathrm{mg} / \mathrm{L}$. Intra-assay coefficients of variation were $11.8 \%$ for TNF- $\alpha, 7.5 \%$ for sTNF-R1, 5.5\% for sTNF-R2, $17.4 \%$ for IL-1 $\beta, 15.5 \%$ for IL-6, 3.6\% for sGP130, and $3.8 \%$ for sIL-6R in this study; interassay coefficients of variation were $<21 \%$ in our validation study conducted at the same core lab [23].

Urinary excretion of $\mathrm{F}_{2}$-IsoPs and their major metabolite, $\mathrm{F}_{2}$-IsoP-M, were measured by gas chromatography/negative ion chemical ionization mass spectrometry (GC/NICI MS) at the Vanderbilt Eicosanoid Core Laboratory. Details of this method have been reported elsewhere [17]. Both $\mathrm{F}_{2}$-IsoPs and $\mathrm{F}_{2}$-IsopM concentrations were expressed as $\mathrm{ng} / \mathrm{mg}$ creatinine. The lower limit of sensitivity was approximately $5 \mathrm{pg}$. The precision of the assay was $\pm 6 \%$ and accuracy was $96 \%$ [17].

\subsection{Statistical analysis}

Participants with less than the detectable limits of inflammatory and oxidative stress markers were excluded from the analysis (TNF- $\alpha, n=4$; sTNF-R1, $n=5$; sTNF-R2, $n=1$; IL- $1 \beta, n=102$; IL-6, $n=$ 71; sGP130, $n=1$; sIL-6R, $n=3$; CRP, $n=90$; $\mathrm{F}_{2}$ IsoPs, $n=0$; and $\mathrm{F}_{2}$-IsopM, $n=0$ ), as were participants with outliers according to a box plot (sTNF-R1, $n=1$; sTNF-R2, $n=3$; sGP130, $n=1$; sIL-6R, $n=$ 6; $\mathrm{F}_{2}$-IsoPs, $n=2$; and $\mathrm{F}_{2}$-IsopM , $n=2$ ).
Log-transformation was conducted to normalize the distribution of the inflammatory markers studied. Geometric means of these markers were obtained based on the least square means estimated using a general linear regression model according to quartiles of anthropometric measurements after adjustment for potential confounding factors. Covariates adjusted for included age; education; occupation; total physical activity; Charlson comorbidity index [24]; history of other infectious or inflammation-related diseases that are not included in the Charlson comorbidity index; menopausal status; cigarette smoking; alcohol consumption; regular use of aspirin or other non-steroidal anti-inflammatory drugs (NSAIDs); regular use of vitamin supplements; dietary intakes of total calories, total fruits, and total vegetables; and assay batch. Use of antibiotics and vitamin supplements in the week before sample collection was also adjusted for in the model. The association of anthropometric measures of obesity with biomarkers was examined with and without adjusting for physical activity. Mutual adjustment for BMI and WHR was performed to evaluate independent effects of these two measures of adiposity on biomarkers.

Tests for linear trend were performed by entering categorical variables as continuous variables in the linear regression models. We also used a restricted cubic spline linear regression model to graphically illustrate the shape of the correlations between anthropometric measures of adiposity and biomarkers. Knots were placed at the $5^{\text {th }}, 50^{\text {th }}$, and $95^{\text {th }}$ percentiles of the distribution of these measurements. We excluded participants with measures of adiposity below the $0.5^{\text {th }}$ and above the $99.5^{\text {th }}$ percentiles from the spline model to minimize the influence of outliers.

In sensitivity analyses, to reduce the influence of potential acute inflammation on our results, participants with $\mathrm{CRP}>10 \mathrm{mg} / \mathrm{L}$ were excluded, and, to check whether non-detection differed by measures of adiposity, participants with less than the detectable limits of markers were included by assigning them a value of one-half the detectable limit for each marker with an undetectable measurement. In addition, we evaluated the association between BMI and inflammatory markers among non-obese women $\left(\mathrm{BMI}<30 \mathrm{~kg} / \mathrm{m}^{2}\right)$ and conducted stratified analyses by chronic infectious or inflammatory disease status. Multicollinearity was not a concern, since the variance inflation factors for all variables were $<3$ (the variance inflation factors were about 1 for most covariates). All statistical tests were two-sided and were performed using SAS statistical software, version 9.1 (SAS Institute, Cary, NC). 
Table 1

Age-adjusted characteristics of study participants according to body mass index and waist circumference: The Shanghai Women's Health Study ${ }^{\mathrm{a}}$

\begin{tabular}{|c|c|c|c|c|c|}
\hline & \multicolumn{4}{|c|}{ Quartile of body mass index $\left(\mathrm{kg} / \mathrm{m}^{2}\right)$} & \multirow{2}{*}{$\begin{array}{l}P \text { for } \\
\text { trend }^{\mathrm{b}}\end{array}$} \\
\hline & $\begin{array}{c}\leqslant 22.3 \\
(n=250)\end{array}$ & $\begin{array}{l}22.4-24.4 \\
(n=251)\end{array}$ & $\begin{array}{l}24.5-26.7 \\
(n=252)\end{array}$ & $\begin{array}{c}>26.8 \\
(n=251)\end{array}$ & \\
\hline $\operatorname{Age}(y)^{\mathrm{c}}$ & $55.4(9.7)$ & $57.0(8.8)$ & $58.5(8.3)$ & $61.4(7.0)$ & $<0.0001$ \\
\hline Education, high school and above $(\%)$ & 38.8 & 34.5 & 35.2 & 19.1 & $<0.0001$ \\
\hline Manual laborers $(\%)$ & 51.0 & 57.7 & 58.3 & 60.9 & 0.12 \\
\hline Cigarette smoking (\%) & 3.3 & 4.4 & 1.6 & 5.3 & 0.13 \\
\hline Alcohol consumption $(\%)$ & 3.9 & 3.2 & 3.3 & 1.5 & 0.54 \\
\hline Postmenopausal (\%) & 73.3 & 74.8 & 76.8 & 72.4 & 0.21 \\
\hline Use of postmenopausal hormones (\%) & 4.0 & 1.5 & 3.3 & 0.8 & 0.10 \\
\hline Use of aspirin or other NSAIDs (\%) & 1.4 & 3.6 & 6.0 & 2.8 & 0.05 \\
\hline History of infectious or inflammatory diseases $(\%)$ & 54.0 & 58.8 & 55.6 & 71.0 & 0.0003 \\
\hline Use of multivitamin supplements $(\%)$ & 23.5 & 18.0 & 18.5 & 14.4 & 0.05 \\
\hline Charlson comorbidity index ${ }^{\mathrm{d}}$ & $0.24(0.04)$ & $0.29(0.04)$ & $0.23(0.04)$ & $0.42(0.05)$ & 0.02 \\
\hline Physical activity (metabolic equivalent hours/wk/y) ${ }^{\mathrm{d}}$ & $107.1(2.7)$ & $108.1(2.7)$ & $107.0(2.7)$ & $107.5(2.8)$ & 0.99 \\
\hline \multicolumn{6}{|l|}{ Dietary intake $\mathrm{d}^{\mathrm{d}}$} \\
\hline Total calories $(\mathrm{kcal} / \mathrm{d})$ & $1601.0(26.0)$ & $1665.1(25.6)$ & $1700.4(25.6)$ & $1684.9(26.1)$ & 0.02 \\
\hline Fruits $(\mathrm{g} / \mathrm{d})$ & $227.8(10.3)$ & $238.2(10.2)$ & $271.4 .0(10.2)$ & $233.0(10.4)$ & 0.29 \\
\hline \multirow[t]{3}{*}{ Vegetables $(\mathrm{g} / \mathrm{d})$} & $276.0(11.0)$ & $298.8(10.8)$ & $313.0(10.8)$ & $282.5(11.0)$ & 0.48 \\
\hline & \multicolumn{4}{|c|}{ Quartile of waist circumference $(\mathrm{cm})$} & $P$ for \\
\hline & $\begin{array}{c}\leqslant 73 \\
(n=203)\end{array}$ & $\begin{array}{c}74-80 \\
(n=293)\end{array}$ & $\begin{array}{c}81-87 \\
(n=253)\end{array}$ & $\begin{array}{c}>88 \\
(n=256)\end{array}$ & trend $^{\mathrm{b}}$ \\
\hline $\operatorname{Age}(y)^{\mathrm{c}}$ & $54.2(9.6)$ & $55.2(9.3)$ & $60.0(7.4)$ & $62.6(5.8)$ & $<0.0001$ \\
\hline Education, high school and above $(\%)$ & 44.0 & 33.1 & 28.1 & 22.1 & $<0.0001$ \\
\hline Manual laborers $(\%)$ & 49.1 & 54.5 & 61.2 & 60.2 & 0.07 \\
\hline Cigarette smoking (\%) & 3.9 & 3.5 & 2.1 & 5.2 & 0.28 \\
\hline Alcohol consumption $(\%)$ & 5.2 & 2.1 & 2.1 & 2.5 & 0.36 \\
\hline Postmenopausal (\%) & 72.6 & 75.9 & 74.7 & 72.7 & 0.40 \\
\hline Use of postmenopausal hormones (\%) & 2.9 & 3.3 & 1.7 & 1.2 & 0.34 \\
\hline Use of aspirin or other NSAIDs (\%) & 3.9 & 3.5 & 2.8 & 3.6 & 0.91 \\
\hline History of infectious or inflammatory diseases $(\%)$ & 52.4 & 51.1 & 60.5 & 76.4 & $<0.0001$ \\
\hline Use of multivitamin supplements $(\%)$ & 23.7 & 17.1 & 17.1 & 18.4 & 0.29 \\
\hline Charlson comorbidity index ${ }^{\mathrm{d}}$ & $0.24(0.04)$ & $0.23(0.04)$ & $0.26(0.04)$ & $0.45(0.05)$ & 0.002 \\
\hline Physical activity (metabolic equivalent hours/wk/y) ${ }^{\mathrm{d}}$ & $107.9(3.1)$ & $109.7(2.5)$ & $106.4(2.7)$ & $105.6(2.8)$ & 0.41 \\
\hline \multicolumn{6}{|l|}{ Dietary intake $\mathrm{d}^{\mathrm{d}}$} \\
\hline Total calories $(\mathrm{kcal} / \mathrm{d})$ & $1581.6(29.1)$ & $1667.3(24.1)$ & $1658.2(25.6)$ & $1728.9(26.3)$ & 0.001 \\
\hline Fruits $(\mathrm{g} / \mathrm{d})$ & $220.8(11.6)$ & $260.7(9.6)$ & $252.7(10.2)$ & $229.2(10.5)$ & 0.92 \\
\hline Vegetables $(\mathrm{g} / \mathrm{d})$ & $262.2(12.3)$ & $310.0(10.2)$ & $292.5(10.8)$ & $297.3(11.1)$ & 0.15 \\
\hline
\end{tabular}

${ }^{\mathrm{a}}$ Except for mean age, data were standardized to the age distribution. ${ }^{\mathrm{b}}$ Linear regression models were used for continuous variables and CochranMantel-Haenszel chi-square tests for categorical variables. ${ }^{\mathrm{c}}$ Mean (SD). ${ }^{\mathrm{d}}$ Mean (SEE). NSAIDs: non-steroidal anti-inflammatory drugs.

\section{Results}

\subsection{Characteristics of study participants}

The mean age \pm SD of study participants was 58.5 \pm 8.8 years. Mean BMI was $24.6 \pm 3.5 \mathrm{~kg} / \mathrm{m}^{2}$ and obesity prevalence $(\mathrm{BMI} \geqslant 30)$ was $6.7 \%$. Study participants' characteristics according to quartiles of BMI and WC are presented in Table 1. Women with higher $\mathrm{BMI}$ and WC were likely to be older and to have lower educational attainment, but higher total energy intake. They were also likely to have a history of infectious or inflammation-related diseases and a higher Charlson comorbidity index. However, the distribution of other inflammation-related factors, such as physical activity, cigarette smoking, or intake of fruits and vegeta- bles, did not depend upon quartile of BMI or WC. All anthropometric measures of adiposity studied (BMI, WHtR, WC, WHR, and HC) were significantly and strongly correlated with each other $(r$ ranged from 0.70 to 0.96 ), with the exception of WHR, which was moderately correlated with BMI $(r=0.44)$ and weakly correlated with HC ( $r=0.20)$ (Supplemental Table 1). Apart from age and menopausal status, the characteristics of this subset of the cohort were not significantly different from the rest of the cohort (data not shown).

\subsection{Correlation between anthropometric measures of adiposity and biomarkers studied}

We used a restricted cubic spline linear regression model to graphically illustrate the shape of the corre- 

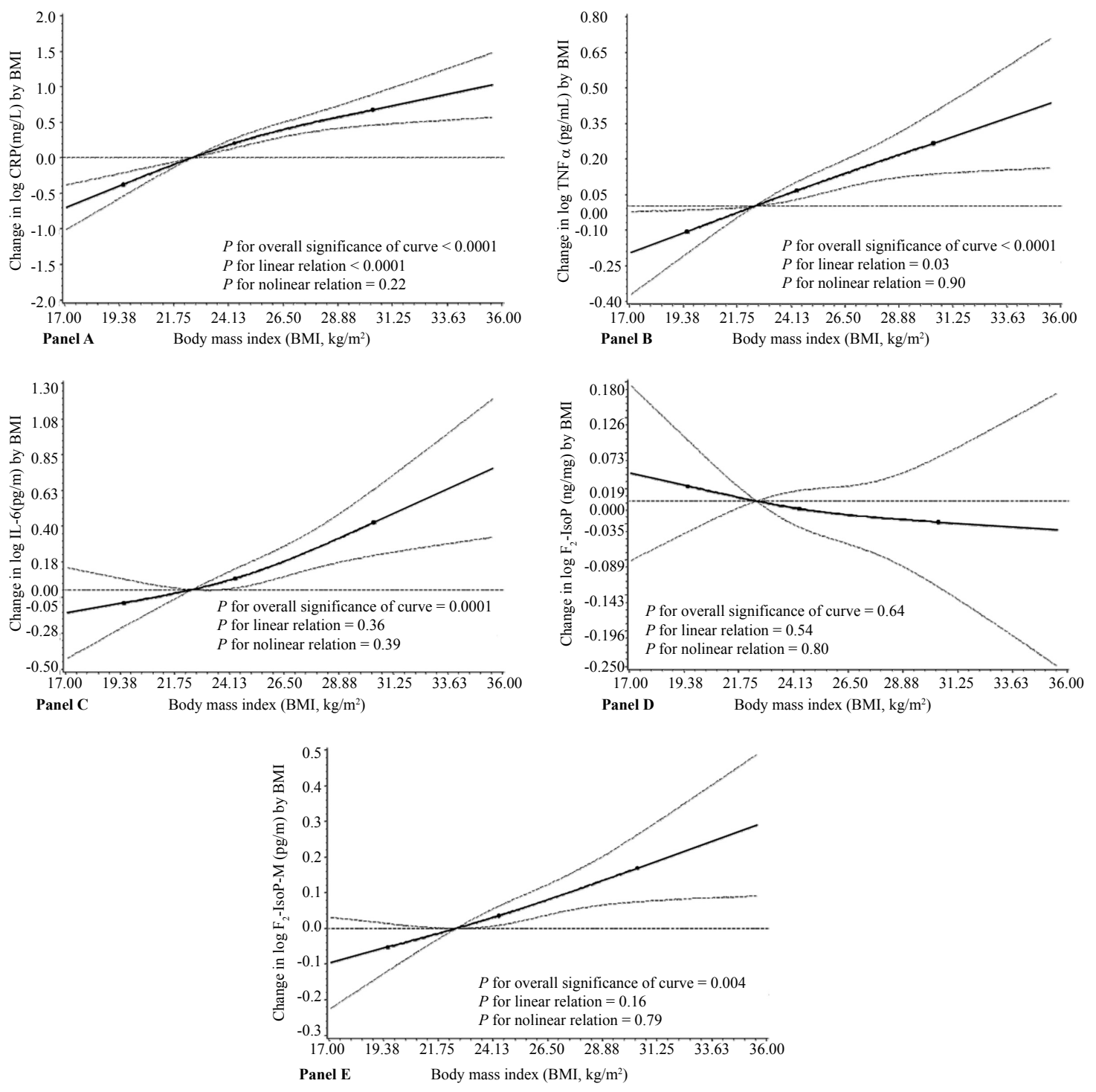

Fig. 1. PANELS A-E. Smoothed plot of the logarithmically transformed CRP (mg/L) (A), TNF $\alpha(\mathrm{pg} / \mathrm{mL})(B), \mathrm{IL}-6$ (pg/mL) (C), $\mathrm{F}_{2}$-IsoP $(\mathrm{ng} / \mathrm{mg})(\mathrm{D})$, and $\mathrm{F}_{2}$-IsoP-M (ng/mg) (E) concentrations relative to the reference according to BMI $\left(\mathrm{kg} / \mathrm{m}^{2}\right)$, estimated by restricted cubic-spline linear regression models with knots placed at the $5^{\text {th }}, 50^{\text {th }}$, and $95^{\text {th }}$ percentiles of BMI, after adjustment for all potential confounding factors. The biomarker value for participants with BMI at the 12.5 percentile (the median of the first quartile) was treated as the reference. Participants with BMI below the $0.5^{\text {th }}$ or above the $99.5^{\text {th }}$ percentiles were not included. Point estimates are indicated by a solid line and $95 \%$ CIs by dashed lines. CRP: C-reactive protein; $\mathrm{F}_{2}$-IsoPs: $15-\mathrm{F}_{2 t}$-isoprostanes; $\mathrm{F}_{2}$-IsoP-M: 2,3-dinor-5,6-dihydro-15-F $2 t$-isoprostane; IL-6: interleukin 6; TNF- $\alpha$ : Tumor necrosis factor $\alpha$.

lations between anthropometric measures of adiposity and biomarkers after adjustment for age, lifestyle factors, and related health conditions. The concentrations of CRP and TNF- $\alpha$ were linearly and positively associated with BMI (Fig. 1, panels A and B), with a $P$ for overall significance of $<0.0001$ for both markers. IL-6 was also positively associated with BMI, although tests for linearity were not statistically significant (Fig. 1, panel C). A similar positive linear association was found for WC with each of these markers (Fig. 2, panels A, B, and C), with a $P$ for overall significance of $\leqslant 0.0001$ for all three markers. Urinary concentrations of the oxidative stress marker $\mathrm{F}_{2}$-IsoPs were not significantly correlated with either BMI (Fig. 1, panel D) or WC (Fig. 2, panel D). However, significant positive associations were found between the major metabolite of $\mathrm{F}_{2}$-IsoPs ( $\mathrm{F}_{2}$-IsoP-M) and BMI (Fig. 1, panel E) and WC (Fig. 2, panel E). 

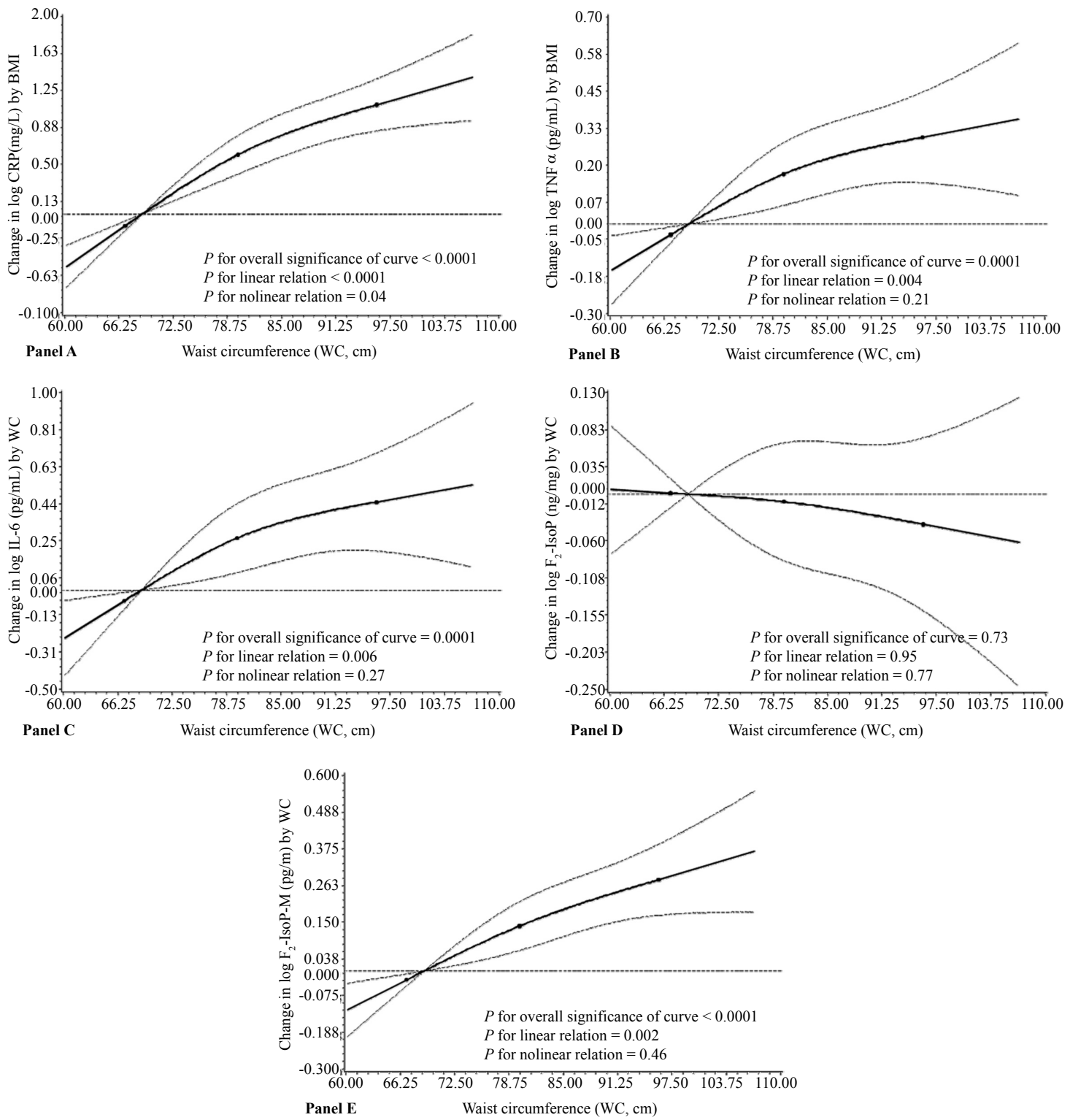

Fig. 2. PANELS A-E. Smoothed plot of the logarithmically transformed CRP (mg/L) (A), TNF $\alpha(\mathrm{pg} / \mathrm{mL})(B), \mathrm{IL}-6$ (pg/mL) (C), $\mathrm{F}_{2}$-IsoP (ng/mg) (D), and $\mathrm{F}_{2}$-IsoP-M (ng/mg) (E) concentrations relative to the reference according to waist circumference (WC, $\mathrm{cm}$ ), estimated by restricted cubic-spline linear regression models with knots placed at the $5^{\text {th }}, 50^{\text {th }}$, and $95^{\text {th }}$ percentiles of WC, after adjustment for all potential confounding factors. The biomarker value for participants with WC at the 12.5 percentile was treated as the reference. Participants with WC below the $0.5^{\text {th }}$ or above the $99.5^{\text {th }}$ percentiles were not included. Point estimates are indicated by a solid line and $95 \%$ CIs by dashed lines. CRP: C-reactive protein; $\mathrm{F}_{2}$-IsoPs: 15- $\mathrm{F}_{2 t}$-isoprostanes; $\mathrm{F}_{2}$-IsoP-M: 2,3-dinor-5,6-dihydro-15- $\mathrm{F}_{2 t}$-isoprostanes; IL-6: interleukin 6; TNF- $\alpha$ : Tumor necrosis factor $\alpha$.

\subsection{Multivariable-adjusted concentrations of biomarkers by categories of anthropometric measures of adiposity}

Multivariable adjusted concentrations of CRP, TNF$\alpha$, sTNF-R1, IL-1 $\beta$, IL-6, and $\mathrm{F}_{2}$-IsoP-M increased with increasing quartiles of BMI (Table 2). The differ- ence in adjusted geometric means of various biomarkers between the highest and lowest quartiles of BMI varied widely, ranging from $9.7 \%$ for sTNF-R1 to $118.0 \%$ for CRP. Similar significant positive associations with WC (Table 2) and WHtR (Supplemental Table 2) were found for CRP, TNF- $\alpha$, sTNF-R1, sTNFR2, IL-6, and $\mathrm{F}_{2}$-IsoP-M. WHR was correlated with 
Table 2

Multivariable-adjusted concentrations of inflammatory and oxidative stress markers in women according to quartiles of body mass index or waist circumference: The Shanghai Women's Health Study ${ }^{a}$

\begin{tabular}{|c|c|c|c|c|c|c|c|c|}
\hline \multirow[t]{2}{*}{ Markers } & \multicolumn{4}{|c|}{ By quartile of body mass index $\left(\mathrm{BMI}, \mathrm{kg} / \mathrm{m}^{2}\right)^{\mathrm{b}}$} & \multicolumn{4}{|c|}{ By quartile of waist circumference $(\mathrm{WC}, \mathrm{cm})^{\mathrm{b}}$} \\
\hline & $n$ & $\begin{array}{c}\text { Geometric } \\
\text { mean (SEE) }\end{array}$ & $\begin{array}{c}\text { Difference } \\
(\%)^{\mathrm{c}}\end{array}$ & $\begin{array}{l}P \text { for } \\
\text { trend }\end{array}$ & $n$ & $\begin{array}{c}\text { Geometric } \\
\text { mean (SEE) }\end{array}$ & $\begin{array}{c}\text { Differenc } \\
(\%)^{\mathrm{c}}\end{array}$ & $\begin{array}{l}P \text { for } \\
\text { trend }\end{array}$ \\
\hline CRP (mg/L) & $\begin{array}{l}171 \\
200 \\
209 \\
210\end{array}$ & $\begin{array}{l}0.78(1.09) \\
1.05(1.08) \\
1.34(1.08) \\
1.70(1.08)\end{array}$ & $\begin{array}{c}\text { Reference } \\
34.62^{\mathrm{d}} \\
71.79^{\mathrm{d}} \\
117.95^{\mathrm{d}}\end{array}$ & $<0.0001$ & $\begin{array}{l}139 \\
236 \\
207 \\
209\end{array}$ & $\begin{array}{l}0.71(1.10) \\
0.94(1.07) \\
1.42(1.08) \\
1.86(1.08)\end{array}$ & $\begin{array}{l}\text { Reference } \\
32.39^{\mathrm{e}} \\
100.00 \\
161.97\end{array}$ & $<0.0001$ \\
\hline TNF- $\alpha(\mathrm{pg} / \mathrm{mL})$ & $\begin{array}{l}247 \\
250 \\
252 \\
248\end{array}$ & $\begin{array}{l}5.24(1.05) \\
5.37(1.05) \\
6.36(1.05) \\
6.86(1.05)\end{array}$ & $\begin{array}{c}\text { Reference } \\
2.48 \\
21.37^{\mathrm{d}} \\
30.92^{\mathrm{d}}\end{array}$ & $<0.0001$ & $\begin{array}{l}203 \\
289 \\
253 \\
253\end{array}$ & $\begin{array}{l}5.07(1.05) \\
5.59(1.04) \\
6.46(1.05) \\
6.55(1.05)\end{array}$ & $\begin{array}{c}\text { Reference } \\
10.26 \\
27.42^{d} \\
29.19^{d}\end{array}$ & 0.0001 \\
\hline sTNF-R1 (pg/mL) & $\begin{array}{l}233 \\
240 \\
233 \\
244\end{array}$ & $\begin{array}{l}1093.5(1.03) \\
1072.1(1.03) \\
1129.5(1.03) \\
1199.0(1.03)\end{array}$ & $\begin{array}{l}\text { Reference } \\
-1.95 \\
3.29 \\
9.65^{\mathrm{e}}\end{array}$ & 0.01 & $\begin{array}{l}187 \\
274 \\
243 \\
247\end{array}$ & $\begin{array}{l}1061.4(1.03) \\
1083.0(1.03) \\
1161.1(1.03) \\
1181.7(1.03)\end{array}$ & $\begin{array}{c}\text { Reference } \\
2.03 \\
9.40^{\mathrm{e}} \\
11.34^{\mathrm{e}}\end{array}$ & 0.006 \\
\hline sTNF-R2 (pg/mL) & $\begin{array}{l}233 \\
240 \\
235 \\
244\end{array}$ & $\begin{array}{l}4243.2(1.02) \\
4210.8(1.02) \\
4235.5(1.02) \\
4504.5(1.02)\end{array}$ & $\begin{array}{l}\text { Reference } \\
-0.76 \\
-0.18 \\
6.16^{\mathrm{e}}\end{array}$ & 0.054 & $\begin{array}{l}187 \\
275 \\
244 \\
247\end{array}$ & $\begin{array}{l}4116.8(1.02) \\
4209.1(1.02) \\
4334.0(1.02) \\
4498.4(1.02)\end{array}$ & $\begin{array}{c}\text { Reference } \\
2.24 \\
5.28 \\
9.27^{\mathrm{d}}\end{array}$ & 0.005 \\
\hline $\mathrm{IL}-1 \beta(\mathrm{pg} / \mathrm{mL})$ & $\begin{array}{l}226 \\
224 \\
225 \\
224\end{array}$ & $\begin{array}{l}1.17(1.08) \\
1.15(1.08) \\
1.24(1.08) \\
1.46(1.08)\end{array}$ & $\begin{array}{c}\text { Reference } \\
-1.71 \\
5.98 \\
24.79^{\mathrm{e}}\end{array}$ & 0.04 & $\begin{array}{l}180 \\
268 \\
232 \\
220\end{array}$ & $\begin{array}{l}1.19(1.09) \\
1.22(1.07) \\
1.34(1.08) \\
1.26(1.09)\end{array}$ & $\begin{array}{c}\text { Reference } \\
2.52 \\
12.61 \\
5.88\end{array}$ & 0.51 \\
\hline IL-6 (pg/mL) & $\begin{array}{l}223 \\
232 \\
244 \\
231\end{array}$ & $\begin{array}{l}3.39(1.08) \\
3.15(1.08) \\
3.72(1.08) \\
4.93(1.08)\end{array}$ & $\begin{array}{l}\text { Reference } \\
-7.08 \\
9.73 \\
45.43^{\mathrm{e}}\end{array}$ & 0.0002 & $\begin{array}{l}181 \\
274 \\
236 \\
240\end{array}$ & $\begin{array}{l}2.94(1.09) \\
3.43(1.07) \\
4.29(1.08) \\
4.34(1.08)\end{array}$ & $\begin{array}{l}\text { Reference } \\
16.67 \\
45.92^{\mathrm{d}} \\
47.62^{\mathrm{d}}\end{array}$ & 0.0003 \\
\hline sGP130 (pg/mL) & $\begin{array}{l}230 \\
239 \\
231 \\
244\end{array}$ & $\begin{array}{l}178319.1(1.02) \\
176296.1(1.02) \\
181659.6(1.02) \\
180006.9(1.02)\end{array}$ & $\begin{array}{l}\text { Reference } \\
-1.13 \\
1.87 \\
0.95\end{array}$ & 0.5 & $\begin{array}{l}185 \\
273 \\
241 \\
246\end{array}$ & $\begin{array}{l}173041.6(1.02) \\
178160.2(1.02) \\
180395.5(1.02) \\
183275.3(1.02)\end{array}$ & $\begin{array}{c}\text { Reference } \\
2.96 \\
4.25 \\
5.91\end{array}$ & 0.06 \\
\hline sIL-6R (pg/mL) & $\begin{array}{l}232 \\
240 \\
232 \\
243\end{array}$ & $\begin{array}{l}20788.5(1.03) \\
21785.2(1.03) \\
21668.0(1.03) \\
22243.3(1.03)\end{array}$ & $\begin{array}{l}\text { Reference } \\
4.79 \\
4.23 \\
7.0\end{array}$ & 0.19 & $\begin{array}{l}186 \\
275 \\
241 \\
246\end{array}$ & $\begin{array}{l}21193.9(1.04) \\
21158.8(1.03) \\
22443.8(1.03) \\
21630.9(1.03)\end{array}$ & $\begin{array}{l}\text { Reference } \\
-0.17 \\
5.90 \\
2.06\end{array}$ & 0.47 \\
\hline F2-IsoPs (ng/mg) & $\begin{array}{l}219 \\
226 \\
232 \\
226\end{array}$ & $\begin{array}{l}1.63(1.04) \\
1.48(1.03) \\
1.54(1.03) \\
1.54(1.04)\end{array}$ & $\begin{array}{l}\text { Reference } \\
-9.20^{\mathrm{e}} \\
-5.52 \\
-5.52\end{array}$ & 0.46 & $\begin{array}{l}183 \\
264 \\
234 \\
223\end{array}$ & $\begin{array}{l}1.55(1.04) \\
1.55(1.03) \\
1.53(1.03) \\
1.57(1.04)\end{array}$ & $\begin{array}{c}\text { Reference } \\
0.00 \\
-1.29 \\
1.29\end{array}$ & 0.84 \\
\hline F2-IsoP-M (ng/mg) & $\begin{array}{l}213 \\
218 \\
223 \\
221\end{array}$ & $\begin{array}{l}0.54(1.03) \\
0.55(1.03) \\
0.59(1.03) \\
0.65(1.03)\end{array}$ & $\begin{array}{c}\text { Reference } \\
1.85 \\
9.26^{\mathrm{e}} \\
20.37^{\mathrm{d}}\end{array}$ & $<0.0001$ & $\begin{array}{l}177 \\
254 \\
226 \\
219\end{array}$ & $\begin{array}{l}0.50(1.04) \\
0.57(1.03) \\
0.60(1.03) \\
0.66(1.04)\end{array}$ & $\begin{array}{c}\text { Reference } \\
14.00^{\mathrm{d}} \\
20.00^{\mathrm{d}} \\
32.00^{\mathrm{d}}\end{array}$ & $<0.0001$ \\
\hline
\end{tabular}

${ }^{a}$ Adjusted for age, education, occupation, cigarette smoking, alcohol consumption, physical activity, menopausal status, regular use of vitamin supplements, regular use of aspirin or other non-steroidal anti-inflammatory drugs, total fruit and vegetable intake, total energy intake, comobidity index, other infectious or inflammation-related diseases, use of antibiotics or vitamin supplements in the week before sample collection, and assay batch using general linear models. ${ }^{\mathrm{b}}$ Quartile cutoffs for body mass index: $22.3,24.4$, and $26.7 \mathrm{~kg} / \mathrm{m}^{2}$; quartile cutoffs for waist circumference: 73,80 , and $87 \mathrm{~cm}$. ${ }^{\mathrm{C}}$ Difference $(\%)=$ (geometric mean of the inflammatory marker for each quartile - geometric mean for the lowest quartile)/geometric mean for the lowest quartile of body mass index or waist circumference. ${ }^{\mathrm{d}} p<0.01$. ${ }^{\mathrm{e}} p<0.05$. CRP: C-reactive protein; $\mathrm{F}_{2}$ IsoPs: $15-\mathrm{F}_{2 t}$-isoprostanes; $\mathrm{F}_{2}$-IsoP-M: 2,3-dinor-5,6-dihydro-15- $\mathrm{F}_{2 t}$-isoprostanes; IL- $\beta$; interleukin 1 $\beta$; IL-6: interleukin 6; sGP130: soluble GP130; sIL-6R: soluble IL-6 receptor; sTNF-R1: soluble tumor necrosis factor receptor 1; sTNF-R2: soluble tumor necrosis factor receptor 2; TNF- $\alpha$ : tumor necrosis factor $\alpha$. 
Table 3

Multiple linear regression analysis for estimation of inflammatory and oxidative stress markers according to anthropometric indices in 1,005 women: The Shanghai Women'S Health Studya

\begin{tabular}{|c|c|c|c|c|}
\hline Dependent variables & Explanatory variables & Standardized beta coefficient & Partial $r^{2}$ & $P$ \\
\hline CRP (mg/L) & $\begin{array}{l}\text { BMI }\left(\mathrm{kg} / \mathrm{m}^{2}\right) \\
\text { WC }(\mathrm{cm}) \\
\text { WHR } \\
\text { WHtR }\end{array}$ & $\begin{array}{l}0.28 \\
0.33 \\
0.25 \\
0.34\end{array}$ & $\begin{array}{l}0.09 \\
0.11 \\
0.07 \\
0.11\end{array}$ & $\begin{array}{l}<0.0001 \\
<0.0001 \\
<0.0001 \\
<0.0001\end{array}$ \\
\hline TNF- $\alpha(\mathrm{pg} / \mathrm{mL})$ & $\begin{array}{l}\text { BMI }\left(\mathrm{kg} / \mathrm{m}^{2}\right) \\
\text { WC }(\mathrm{cm}) \\
\text { WHR } \\
\text { WHtR }\end{array}$ & $\begin{array}{l}0.14 \\
0.13 \\
0.09 \\
0.15\end{array}$ & $\begin{array}{l}0.03 \\
0.02 \\
0.01 \\
0.02\end{array}$ & $\begin{aligned}< & 0.0001 \\
< & 0.0001 \\
& 0.002 \\
< & 0.0001\end{aligned}$ \\
\hline sTNF-R1 (pg/mL) & $\begin{array}{l}\text { BMI }\left(\mathrm{kg} / \mathrm{m}^{2}\right) \\
\text { WC }(\mathrm{cm}) \\
\text { WHR } \\
\text { WHtR }\end{array}$ & $\begin{array}{l}0.10 \\
0.11 \\
0.03 \\
0.09\end{array}$ & $\begin{array}{l}0.01 \\
0.01 \\
0.003 \\
0.01\end{array}$ & $\begin{array}{l}0.004 \\
0.002 \\
0.32 \\
0.02\end{array}$ \\
\hline sTNF-R2 (pg/mL) & $\begin{array}{l}\text { BMI }\left(\mathrm{kg} / \mathrm{m}^{2}\right) \\
\text { WC }(\mathrm{cm}) \\
\text { WHR } \\
\text { WHtR }\end{array}$ & $\begin{array}{l}0.09 \\
0.10 \\
0.07 \\
0.08\end{array}$ & $\begin{array}{l}0.01 \\
0.01 \\
0.01 \\
0.01\end{array}$ & $\begin{array}{l}0.01 \\
0.004 \\
0.03 \\
0.02\end{array}$ \\
\hline $\mathrm{IL}-1 \beta(\mathrm{pg} / \mathrm{mL})$ & $\begin{array}{l}\text { BMI }\left(\mathrm{kg} / \mathrm{m}^{2}\right) \\
\text { WC }(\mathrm{cm}) \\
\text { WHR } \\
\text { WHtR }\end{array}$ & $\begin{array}{l}0.05 \\
0.03 \\
0.001 \\
0.04\end{array}$ & $\begin{array}{l}0.01 \\
0.002 \\
0.0000001 \\
0.003\end{array}$ & $\begin{array}{l}0.08 \\
0.37 \\
0.97 \\
0.19\end{array}$ \\
\hline IL-6 (pg/mL) & $\begin{array}{l}\text { BMI }\left(\mathrm{kg} / \mathrm{m}^{2}\right) \\
\text { WC }(\mathrm{cm}) \\
\text { WHR } \\
\text { WHtR }\end{array}$ & $\begin{array}{l}0.13 \\
0.13 \\
0.04 \\
0.15\end{array}$ & $\begin{array}{l}0.02 \\
0.02 \\
0.003 \\
0.03\end{array}$ & $\begin{aligned}< & 0.0001 \\
< & 0.0001 \\
& 0.16 \\
< & 0.0001\end{aligned}$ \\
\hline sGP130 (pg/mL) & $\begin{array}{l}\text { BMI }\left(\mathrm{kg} / \mathrm{m}^{2}\right) \\
\text { WC }(\mathrm{cm}) \\
\text { WHR } \\
\text { WHtR }\end{array}$ & $\begin{array}{l}0.03 \\
0.05 \\
0.06 \\
0.05\end{array}$ & $\begin{array}{l}0.001 \\
0.002 \\
0.001 \\
0.002\end{array}$ & $\begin{array}{l}0.42 \\
0.13 \\
0.09 \\
0.15\end{array}$ \\
\hline sIL-6R (pg/mL) & $\begin{array}{l}\text { BMI }\left(\mathrm{kg} / \mathrm{m}^{2}\right) \\
\text { WC }(\mathrm{cm}) \\
\text { WHR } \\
\text { WHtR }\end{array}$ & $\begin{aligned} & 0.04 \\
- & 0.002 \\
- & 0.02 \\
- & 0.005\end{aligned}$ & $\begin{array}{l}0.002 \\
0.0001 \\
0.0003 \\
0.0001\end{array}$ & $\begin{array}{l}0.22 \\
0.95 \\
0.49 \\
0.90\end{array}$ \\
\hline F2-IsoPs (ng/mg) & $\begin{array}{l}\text { BMI }\left(\mathrm{kg} / \mathrm{m}^{2}\right) \\
\text { WC }(\mathrm{cm}) \\
\text { WHR } \\
\text { WHtR }\end{array}$ & $\begin{array}{c}-0.04 \\
-0.03 \\
0.03 \\
0.007\end{array}$ & $\begin{array}{l}0.001 \\
0.000003 \\
0.001 \\
0.01\end{array}$ & $\begin{array}{l}0.26 \\
0.44 \\
0.46 \\
0.87\end{array}$ \\
\hline F2-IsoPs-M (ng/mg) & $\begin{array}{l}\text { BMI }\left(\mathrm{kg} / \mathrm{m}^{2}\right) \\
\text { WC }(\mathrm{cm}) \\
\text { WHR } \\
\text { WHtR }\end{array}$ & $\begin{array}{l}0.16 \\
0.21 \\
0.18 \\
0.24\end{array}$ & $\begin{array}{l}0.03 \\
0.05 \\
0.03 \\
0.06\end{array}$ & $\begin{array}{l}<0.0001 \\
<0.0001 \\
<0.0001 \\
<0.0001\end{array}$ \\
\hline
\end{tabular}

${ }^{a}$ Adjusted for age, education, occupation, cigarette smoking, alcohol consumption, physical activity, menopausal status, regular use of vitamin supplements, regular use of aspirin or other non-steroidal anti-inflammatory drugs, total fruit and vegetable intake, total energy intake, Charlson comobidity index, other infectious or inflammation-related diseases, use of antibiotics or vitamin supplements in the week before sample collec-

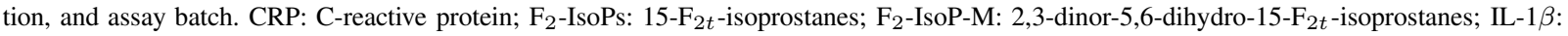
interleukin 1 $\beta$; IL-6: interleukin 6; MET: metabolic equivalent; sGP130: soluble GP130; sIL-6R: soluble IL-6 receptor; sTNF-R1: soluble tumor necrosis factor receptor 1; sTNF-R2: soluble tumor necrosis factor receptor 2; TNF- $\alpha$ : tumor necrosis factor $\alpha$; WC: waist circumference; WHR: waist-to-hip ratio; WHtR: waist-to-height ratio.

some but not all of these markers (Supplemental Table 2), and the strength of the correlations for WHR was somewhat weaker than the correlations for BMI, $\mathrm{WHtR}$, and WC. Analyses of these anthropometric measures of adiposity with and without further adjustment for physical activity yielded almost identical results.

\subsection{Correlation between soluble receptors and their ligands}

sTNF-R1 and sTNF-R2 were modestly correlated with TNF- $\alpha$ (Spearman $r=0.23$ and 0.30, respectively). Correlations between soluble TNF receptors and anthropometric measures of adiposity were weaker 
than those for TNF- $\alpha$ (Table 2). IL-6 and its receptors (sIL-6R and sGP130) were not significantly correlated with each other (Spearman $r=-0.04$ and 0.04 , respectively). BMI and WC were correlated with IL-6 but not with its soluble receptors (Table 2). We also evaluated the ratios of TNF- $\alpha$ and IL- 6 to their soluble receptors in relation to anthropometric measures of adiposity. No significant correlations were found (data not shown).

\subsection{Explanatory ability of anthropometric measures of adiposity}

Partial $r^{2}$ was used to assess the contribution of anthropometric measures of adiposity to variations in inflammatory/oxidative stress markers when other explanatory variables were held constant. For each specific biomarker, different anthropometric measures of adiposity showed similar explanatory ability (partial $r^{2}$ ) in the fully adjusted model, although the partial $r^{2}$ of WHtR and WC for CRP and of WHtR for $\mathrm{F}_{2}$ IsoP-M were slightly greater than other anthropometric measures of adiposity (Table 3 ). Of the biomarkers studied, the biggest partial $r^{2}$ was found for CRP; approximately $11 \%$ of variation in CRP can be explained by either WC or WHtR, after accounting for other explanatory variables. Similarly, the standardized beta coefficients associated with various anthropometric measures of adiposity for each specific biomarker were comparable, although the coefficient associated with WHR was, in general, smaller than other measures of adiposity studied.

\subsection{Effect of fat distribution and sensitivity analyses}

Mutual adjustment for BMI and WC was not conducted, because of concerns about the high collinearity between these two variables $(r=0.83)$ (Supplemental Table 1). Mutual adjustment for BMI and WHR ( $r=$ 0.44) was conducted, which resulted in slight changes in the associations of BMI with the biomarkers studied (Supplemental Table 3). However, additional adjustment for BMI substantially attenuated the association of WHR and TNF- $\alpha$.

Exclusion of participants with CRP $>10 \mathrm{mg} / \mathrm{L}(n=$ $29,2.89 \%$ ) did not markedly change the results, nor did inclusion of participants with less than the detectable limits of markers (data not shown). We also conducted analyses restricted to non-obese women (BMI $<30 \mathrm{~kg} / \mathrm{m}^{2} ; n=938,93.3 \%$ ). Results were similar to those observed for the entire study population, although correlations between BMI and some of the biomarkers studied became slightly weaker (data not shown). We further evaluated whether the association between anthropometric measures of adiposity and inflammation or oxidative stress differed by prevalent health conditions, including history of tuberculosis, chronic bronchitis, asthma, chronic gastritis, chronic hepatitis, ulcerative colitis, diabetes, hypertension, or coronary heart disease. No significant effect modification by the status of these health conditions was suggested (all $P$ for interaction $>0.05$ ).

\section{Discussion}

In this relatively lean population of 1,005 Chinese women, measures of overall adiposity (such as BMI) and central adiposity (such as WC) were found to be positively correlated with circulating inflammatory (CRP, TNF- $\alpha$, sTNF-R1, sTNF-R2, IL-1 $\beta$, and IL$6)$ and urinary oxidative stress markers $\left(\mathrm{F}_{2}\right.$-IsoP-M). These associations were independent of age, socioeconomic status, and other inflammation-related factors, such as lifestyle and dietary factors, inflammationrelated health conditions, and medication use.

Many epidemiological studies and preclinical observations have demonstrated a relationship between obesity and low-grade chronic inflammation [2-4,6,7]. Most previous studies have largely involved populations with a high prevalence of obesity $(29 \%-46 \%)$ [4, $6,7]$. Our study provides support for and extends previous findings by showing a continuous, linear, and positive relation between inflammatory and oxidative stress markers and anthropometric measures of adiposity in a relatively lean population with a prevalence of obesity of $6.7 \%$. This finding is also supported by the observation that many obesity-related diseases, such as cardiovascular disease, are seen in individuals with "normal/healthy" body weight $[2,10,25]$. Our data further underscore the importance of weight control in the prevention of many obesity-related diseases.

IL-6, IL- $1 \beta$, and TNF- $\alpha$ are three pivotal proinflammatory cytokines that have been found to be involved in many obesity-related diseases [26,27]. CRP, a sensitive marker of low-grade systemic inflammation, is produced in the liver through the stimulation of pro-inflammatory cytokines, including mainly IL-6, IL-1 $\beta$, and TNF- $\alpha$ [28]. As a downstream biomarker, CRP provides functional integration of overall upstream cytokine activation [29]. Most previous studies of obesity and inflammation have focused mainly on 
CRP $[3,5,6]$. In this study, we comprehensively evaluated a panel of inflammatory markers and soluble receptors of cytokines. Overall, values for partial $r^{2}$, which reflects the proportion of variation in biomarker levels that can be explained by anthropometric measures of adiposity when other explanatory variables are held constant, were small, ranging from $1 \%$ for sTNFRs to $11 \%$ for CRP. The biggest partial $r^{2}$ was observed for CRP, suggesting that CRP may be the most appropriate marker (with respect to strength of the correlation) for describing the obesity and inflammation association.

BMI, a measure of general adiposity, has been used as the primary measure of body fatness in most previous studies [2,4-6]. However, this measure is unable to distinguish fat mass and non-fat mass, particularly among elderly people. On the other hand, WC, WHtR, and WHR, measures of central adiposity, are less affected by loss of muscle mass during aging and represent a measure of adiposity that takes into account the accumulation of abdominal fat [3032]. Among middle-aged and elderly adults, accumulation of visceral fat has been strongly associated with inflammation in some studies [2,10-13], particularly in women [33-35]. However, no heterogeneity in the association with visceral versus subcutaneous adipose tissue volume, as assessed by computerized tomography, was observed in the Framingham Heart Study [13]. Measures of both general and central adiposity have been positively and similarly associated with inflammation and oxidative stress [13]. Similar results were also found in our study. Various measures of adiposity exhibit similar explanatory ability (partial $r^{2}$ ) for variations of each specific biomarker.

sTNF-R2 is considered to better reflect long-term average circulating concentrations of TNF- $\alpha$ and has been used as an indicator of TNF- $\alpha$ activity in epidemiological studies [36,37]. However, few studies have comprehensively evaluated the relation of soluble receptors of cytokines with their ligands and with other inflammatory determinants to help understand the biological correlates of these soluble receptors [38, 39]. In this study, we found that the correlations between soluble receptors (sTNF-R1, sTNF-R2, sIL-6R, and sGP130) and their ligands (TNF- $\alpha$ and IL-6) were weak. Anthropometric measures of adiposity were related to IL-6 and TNF- $\alpha$, but were not or were only weakly related to their soluble receptors. Therefore, using soluble receptor levels to represent TNF- $\alpha$ or IL6 levels is not supported by this study. In fact, recognition of the biological action of soluble receptors has led to their therapeutic use as cytokine inhibitors in preclinical studies [40].

In a multi-investigator study sponsored by the National Institute of Environmental Health Sciences (NIEHS), termed the Biomarkers of Oxidative Stress (BOSS) Study, quantification of $\mathrm{F}_{2}$-IsoPs by mass spectrometry was found to be the most accurate method to assess endogenous oxidative stress [17]. Positive relationships between $\mathrm{F}_{2}$-IsoPs and the anthropometric measurements $\mathrm{BMI}$ and WHR have been found in some [8,9] but not all previous studies [18]. One possible reason for this inconsistency, besides study design and subject characteristics, is the method used to quantify $\mathrm{F}_{2}$-IsoPs. In previous studies, immunoassays for $\mathrm{F}_{2}$-IsoPs were frequently used, in which a cross-reactivity exists between antibodies for $\mathrm{F}_{2}$-IsoPs and structurally similar isomers [18], such as $\mathrm{F}_{2}$-IsoP metabolites [41]. In addition, unlike $\mathrm{F}_{2}$-IsoPs, $\mathrm{F}_{2}$-IsoP metabolite in urine is not subject to autoxidation or renal production [17]. We measured urinary $\mathrm{F}_{2}$-IsoPs and their major metabolite, $\mathrm{F}_{2}$-IsoP-M, by a mass spectrometry-based method. Our finding of a significant positive association of anthropometric measures of adiposity with $\mathrm{F}_{2}$-IsoP-M but not $\mathrm{F}_{2}$-IsoPs suggests that $\mathrm{F}_{2}$-IsoP-M may be a better marker of in vivo oxidative stress than its parent compounds. This finding is also supported by another parallel study conducted in the SWHS that recently and independently evaluated the obesity and oxidative stress association [42]. In addition, increased risk of breast cancer was found to be more closely related to urinary $\mathrm{F}_{2}$-IsoP-M than $\mathrm{F}_{2}$-IsoPs in the SWHS [18]. Clearly, this hypothesis needs to be further investigated.

Several methodological limitations of this study should be considered. The study was cross-sectional in design; thus, no causal relationships can be inferred. Individuals in different categories of obesity are also likely to differ in several other respects. For example, health conditions, particularly some inflammationrelated diseases, may result in changes in anthropometric measures of adiposity, thus potentially biasing the obesity and inflammation association. However, our study found no significant heterogeneity in the association for groups with versus without a history of chronic infectious or inflammatory diseases. In addition, although detailed information on a wide range of factors related to inflammation and oxidative stress was available, allowing us to control for potential confounding by these factors, we could not completely rule out the possibility of residual confounding due to unmeasured or inadequately measured covariates. 
In conclusion, this study suggests that measures of both general (measured by BMI) and central adiposity (measured by WC and WHtR) were positively associated with inflammation and oxidative stress in women. $\mathrm{F}_{2}$-IsoP-M may be a better marker of in vivo oxidative stress than its parent compounds $\mathrm{F}_{2}$-IsoPs. Because the proportion of variation in inflammation and oxidative stress that can be explained by anthropometric measures of adiposity was small, further investigations are clearly needed to identify modifiable and genetic factors related to chronic inflammation and oxidative stress in humans.

\section{Acknowledgments}

We are grateful to the participants and research staff of the Shanghai Women's Health Study for their contributions to the study. We thank Ms. Bethanie Rammer for her assistance in editing and preparing the manuscript. We also thank Regina Courtney and Rodica Cal-Chris for sample preparation.

\section{Funding sources}

This study was supported by US National Institute of Health (grants R01CA122364 to G. Yang, R37CA070867 to W. Zheng, R01HL095931 to X. Zhang, and N02 CP1101066 to X.O. Shu). The plasma and urine sample preparation was performed at the Survey and Biospecimen Shared Resource, which is supported in part by the Vanderbilt-Ingram Cancer Center (P30 CA68485).

\section{References}

[1] A.S. Greenberg and M.S. Obin, Obesity and the role of adipose tissue in inflammation and metabolism, Am J Clin Nutr 83 (2006), 461S-465S.

[2] A.E. Hak, C.D. Stehouwer, M.L. Bots, K.H. Polderman, C.G. Schalkwijk, I.C. Westendorp, A. Hofman and J.C. Witteman, Associations of C-reactive protein with measures of obesity, insulin resistance, and subclinical atherosclerosis in healthy, middle-aged women, Arteriosclerosis, Thrombosis, and Vascular Biology 19 (1999), 1986-1991.

[3] J.C. Chambers, S. Eda, P. Bassett, Y. Karim, S.G. Thompson, J.R. Gallimore, M.B. Pepys and J.S. Kooner, C-reactive protein, insulin resistance, central obesity, and coronary heart disease risk in Indian Asians from the United Kingdom compared with European whites, Circulation 104 (2001), 145150 .
[4] X.M. Nguyen, J. Lane, B.R. Smith and N.T. Nguyen, Changes in inflammatory biomarkers across weight classes in a representative US population: A link between obesity and inflammation, J Gastrointest Surg 13 (2009), 1205-1212.

[5] T.W. Kao, I.S. Lu, K.C. Liao, H.Y. Lai, C.H. Loh and H.K. Kuo, Associations between body mass index and serum levels of C-reactive protein, S Afr Med J 99 (2009), 326-330.

[6] S.E. Kahn, B. Zinman, S.M. Haffner, M.C. O’Neill, B.G. Kravitz, D. Yu, M.I. Freed, W.H. Herman, R.R. Holman, N.P. Jones, J.M. Lachin and G.C. Viberti, Obesity is a major determinant of the association of C-reactive protein levels and the metabolic syndrome in type 2 diabetes, Diabetes 55 (2006), 2357-2364.

[7] D.B. Panagiotakos, C. Pitsavos, M. Yannakoulia, C. Chrysohoou and C. Stefanadis, The implication of obesity and central fat on markers of chronic inflammation: The ATTICA study, Atherosclerosis 183 (2005), 308-315.

[8] L.D. Kauffman, R.J. Sokol, R.H. Jones, J.A. Awad, M.J. Rewers and J.M. Norris, Urinary F2-isoprostanes in young healthy children at risk for type 1 diabetes mellitus, Free Radic Biol Med 35 (2003), 551-557.

[9] J.F. Keaney, Jr., M.G. Larson, R.S. Vasan, P.W. Wilson, I. Lipinska, D. Corey, J.M. Massaro, P. Sutherland, J.A. Vita and E.J. Benjamin, Obesity and systemic oxidative stress: Clinical correlates of oxidative stress in the Framingham Study, Arteriosclerosis, Thrombosis, and Vascular Biology 23 (2003), 434-439.

[10] Y. Saijo, N. Kiyota, Y. Kawasaki, Y. Miyazaki, J. Kashimura, M. Fukuda and R. Kishi, Relationship between C-reactive protein and visceral adipose tissue in healthy Japanese subjects, Diabetes Obes Metab 6 (2004), 249-258.

[11] E. Lapice, S. Maione, L. Patti, P. Cipriano, A.A. Rivellese, G. Riccardi and O. Vaccaro, Abdominal adiposity is associated with elevated C-reactive protein independent of BMI in healthy nonobese people, Diabetes care 32 (2009), 17341736.

[12] B. Collier, L. Dossett, J. Shipman, M. Day, G. Lawson, R. Sawyer and A. May, Visceral adiposity is not associated with inflammatory markers in trauma patients, J Trauma 68 (2010), 57-61.

[13] K.M. Pou, J.M. Massaro, U. Hoffmann, R.S. Vasan, P. Maurovich-Horvat, M.G. Larson, J.F. Keaney, Jr., J.B. Meigs, I. Lipinska, S. Kathiresan, J.M. Murabito, C.J. O'Donnell, E.J. Benjamin and C.S. Fox, Visceral and subcutaneous adipose tissue volumes are cross-sectionally related to markers of inflammation and oxidative stress: The Framingham Heart Study, Circulation 116 (2007), 1234-1241.

[14] G.L. Milne, H. Yin, J.D. Brooks, S. Sanchez, R.L. Jackson and J.D. Morrow, Quantification of F2-isoprostanes in biological fluids and tissues as a measure of oxidant stress, Methods in enzymology 433 (2007), 113-126.

[15] L.J. Roberts and J.D. Morrow, Measurement of F(2)isoprostanes as an index of oxidative stress in vivo, Free Radic Biol Med 28 (2000), 505-513.

[16] M. Comporti, C. Signorini, B. Arezzini, D. Vecchio, B. Monaco and C. Gardi, F2-isoprostanes are not just markers of oxidative stress, Free Radic Biol Med 44 (2008), 247-256.

[17] G.L. Milne, S.C. Sanchez, E.S. Musiek and J.D. Morrow, Quantification of F2-isoprostanes as a biomarker of oxidative stress, Nat Protoc 2 (2007), 221-226.

[18] Q. Dai, Y.T. Gao, X.O. Shu, G. Yang, G. Milne, Q. Cai, W. Wen, N. Rothman, H. Cai, H. Li, Y. Xiang, W.H. Chow and W. Zheng, Oxidative stress, obesity, and breast cancer risk: Re- 
sults from the Shanghai Women's Health Study, J Clin Oncol 27 (2009), 2482-2488.

[19] X.O. Shu, G. Yang, F. Jin, D. Liu, L. Kushi, W. Wen, Y.T. Gao and W. Zheng, Validity and reproducibility of the food frequency questionnaire used in the Shanghai Women's Health Study, Eur J Clin Nutr 58 (2004), 17-23.

[20] W. Zheng, W.H. Chow, G. Yang, F. Jin, N. Rothman, A. Blair, H.L. Li, W.Q. Wen, B.T. Ji, Q. Li, X.O. Shu and Y.T. Gao, The Shanghai women's health study: Rationale, study design, and baseline characteristics, American Journal of Epidemiology 162 (2005), 1123-1131.

[21] C.E. Matthews, X.O. Shu, G. Yang, F. Jin, B.E. Ainsworth, D. Liu, Y.T. Gao and W. Zheng, Reproducibility and validity of the Shanghai women's health study physical activity questionnaire, Am J Epidemiol 158 (2003), 1114-1122.

[22] Y.X. Yang, G.Y. Wang and X.C. Pan, China food composition tables 2002, Beijing University Medical Press, Beijing, China, 2002.

[23] S.A. Lee, W.H. Xu, W. Zheng, H. Li, G. Yang, Y.B. Xiang and X.O. Shu, Physical activity patterns and their correlates among Chinese men in Shanghai, Med Sci Sports Exerc 39 (2007), 1700-1707.

[24] W. D'hoore, A. Bouckaert and C. Tilquin, Practical considerations on the use of the Charlson comorbidity index with administrative data bases, J Clin Epidemiol 49 (1996), 14291433.

[25] H.H. Hermsdorff, M.A. Zulet, B. Puchau, and J.A. Martinez, Central adiposity rather than total adiposity measurements are specifically involved in the inflammatory status from healthy young adults, Inflammation 34 (2011), 161-170.

[26] R.B. Goldberg, Cytokine and cytokine-like inflammation markers, endothelial dysfunction, and imbalanced coagulation in development of diabetes and its complications, J Clin Endocrinol Metab 94 (2009), 3171-3182.

[27] P. Trayhurn and I.S. Wood, Adipokines: Inflammation and the pleiotropic role of white adipose tissue, Br J Nutr 92 (2004), 347-355.

[28] U.N. Das, Is obesity an inflammatory condition?, Nutrition Burbank, Los Angeles County, Calif. 17 (2001), 953-966.

[29] Y. Hattori, M. Matsumura and K. Kasai, Vascular smooth muscle cell activation by C-reactive protein, Cardiovasc Res 58 (2003), 186-195.

[30] C.M. Lee, R.R. Huxley, R.P. Wildman and M. Woodward, Indices of abdominal obesity are better discriminators of cardiovascular risk factors than BMI: A meta-analysis, J Clin Epidemiol 61 (2008), 646-653.

[31] M.F. Leitzmann, S.C. Moore, A. Koster, T.B. Harris, Y. Park, A. Hollenbeck and A. Schatzkin, Waist circumference as compared with body-mass index in predicting mortality from specific causes, PLoS One 6 (2011), e18582.

[32] A.H. Kissebah, N. Vydelingum, R. Murray, D.J. Evans, A.J. Hartz, R.K. Kalkhoff and P.W. Adams, Relation of body fat distribution to metabolic complications of obesity, J Clin Endocrinol Metab 54 (1982), 254-260.

[33] J. Saltevo, M. Vanhala, H. Kautiainen, E. Kumpusalo and M. Laakso, Gender differences in C-reactive protein, interleukin1 receptor antagonist and adiponectin levels in the metabolic syndrome: A population-based study, Diabetic medicine: A journal of the British Diabetic Association 25 (2008), 747750.

[34] A. Cartier, M. Cote, I. Lemieux, L. Perusse, A. Tremblay, C. Bouchard and J.P. Despres, Sex differences in inflammatory markers: What is the contribution of visceral adiposity? Am J Clin Nutr 89 (2009), 1307-1314.

[35] H.H. Hermsdorff, A.C. Volp, B. Puchau, K.B. Barbosa, M.A. Zulet, J. Bressan and J.A. Martinez, Contribution of gender and body fat distribution to inflammatory marker concentrations in apparently healthy young adults, Inflamm Res $\mathbf{6 1}$ (2012), 427-435.

[36] G.S. Hotamisligil, P. Arner, R.L. Atkinson and B.M. Spiegelman, Differential regulation of the p80 tumor necrosis factor receptor in human obesity and insulin resistance, Diabetes $\mathbf{4 6}$ (1997), 451-455.

[37] J.K. Pai, T. Pischon, J. Ma, J.E. Manson, S.E. Hankinson, K. Joshipura, G.C. Curhan, N. Rifai, C.C. Cannuscio, M.J. Stampfer and E.B. Rimm, Inflammatory markers and the risk of coronary heart disease in men and women, $N$ Engl J Med 351 (2004), 2599-2610.

[38] A. Halasz, E. Cserhati, R. Magyar, M. Kovacs and K. Cseh, Role of TNF-alpha and its 55 and $75 \mathrm{kDa}$ receptors in bronchial hyperreactivity, Respir Med 96 (2002), 262-267.

[39] J.K. Pai, S.E. Hankinson, R. Thadhani, N. Rifai, T. Pischon and E.B. Rimm, Moderate alcohol consumption and lower levels of inflammatory markers in US men and women, Atherosclerosis 186 (2006), 113-120.

[40] R. Fernandez-Botran, Soluble cytokine receptors: Basic immunology and clinical applications, Crit Rev Clin Lab Sci 36 (1999), 165-224.

[41] D. Pratico, J.A. Lawson, J. Rokach and G.A. FitzGerald, The isoprostanes in biology and medicine, Trends Endocrinol Metab 12 (2001), 243-247.

[42] T. Dorjgochoo, Y.T. Gao, W.H. Chow, X.O. Shu, G. Yang, Q. Cai, N. Rothman, H. Cai, H. Li, X. Deng, M.J. Shrubsole, H. Murff, G. Milne, W. Zheng and Q. Dai, Obesity, age, and oxidative stress in middle-aged and older women, Antioxid Redox Signal 14 (2011), 2453-2460. 


\section{Supplementary material}

Supplemental Table 1

Spearman correlation coefficients between anthropometric measures of obesity: The Shanghai Women's Health Study ${ }^{\mathrm{a}}$

\begin{tabular}{lccc}
\hline Variable & Body mass index $\left(\mathrm{kg} / \mathrm{m}^{2}\right)$ & Waist circumference $(\mathrm{cm})$ & Waist-to-hip ratio \\
\hline Waist circumference $(\mathrm{cm})$ & 0.83 & & Waist-to-height ratio \\
Waist-to-hip ratio & 0.44 & 0.70 & 0.71 \\
Waist-to-height ratio & 0.83 & 0.96 & 0.20 \\
Hip circumference $(\mathrm{cm})$ & 0.80 & 0.82 & 0.75 \\
\hline
\end{tabular}

${ }^{a}$ All $P<0.05$ 
Supplemental Table 2

Multivariable-adjusted concentrations of inflammatory and oxidative stress markers in women according to quartiles of waist-to-height ratio and waist-to-hip ratio: The Shanghai Women's Health Study ${ }^{a}$

\begin{tabular}{|c|c|c|c|c|c|c|c|c|}
\hline \multirow[t]{2}{*}{ Markers } & \multicolumn{4}{|c|}{ By quartile of waist-to-height ratio ${ }^{\mathrm{b}}$} & \multicolumn{4}{|c|}{ By quartile of waist-to-hip ratio ${ }^{b}$} \\
\hline & $n$ & $\begin{array}{c}\text { Geometric } \\
\text { mean (SEE) }\end{array}$ & $\begin{array}{c}\text { Difference } \\
(\%)^{\mathrm{c}}\end{array}$ & $\begin{array}{l}P \text { for } \\
\text { trend }\end{array}$ & $n$ & $\begin{array}{c}\text { Geometric } \\
\text { mean (SEE) }\end{array}$ & $\begin{array}{c}\text { Difference } \\
(\%)^{\mathrm{c}}\end{array}$ & $\begin{array}{l}P \text { for } \\
\text { trend }\end{array}$ \\
\hline $\mathrm{CRP}(\mathrm{mg} / \mathrm{L})$ & $\begin{array}{l}176 \\
199 \\
210 \\
206\end{array}$ & $\begin{array}{l}0.74(1.09) \\
0.92(1.08) \\
1.43(1.08) \\
1.90(1.08)\end{array}$ & $\begin{array}{c}\text { Reference } \\
24.32 \\
93.24^{\mathrm{d}} \\
156.76^{\mathrm{d}}\end{array}$ & $<0.0001$ & $\begin{array}{l}185 \\
206 \\
195 \\
204\end{array}$ & $\begin{array}{l}0.84(1.08) \\
1.01(1.08) \\
1.37(1.08) \\
1.70(1.08)\end{array}$ & $\begin{array}{c}\text { Reference } \\
20.24 \\
63.10^{\mathrm{d}} \\
102.38^{\mathrm{d}}\end{array}$ & $<0.0001$ \\
\hline TNF- $\alpha(\mathrm{pg} / \mathrm{mL})$ & $\begin{array}{l}248 \\
250 \\
249 \\
251\end{array}$ & $\begin{array}{l}4.96(1.05) \\
5.76(1.05) \\
6.19(1.05) \\
6.94(1.05)\end{array}$ & $\begin{array}{l}\text { Reference } \\
16.13^{\mathrm{e}} \\
24.80^{\mathrm{d}} \\
39.92^{\mathrm{d}}\end{array}$ & $<0.0001$ & $\begin{array}{l}250 \\
247 \\
245 \\
255\end{array}$ & $\begin{array}{l}5.44(1.05) \\
5.68(1.05) \\
5.99(1.05) \\
6.60(1.05)\end{array}$ & $\begin{array}{c}\text { Reference } \\
4.41 \\
10.11 \\
21.32^{\mathrm{d}}\end{array}$ & 0.003 \\
\hline sTNF-R1 (pg/mL) & $\begin{array}{l}232 \\
236 \\
242 \\
241\end{array}$ & $\begin{array}{l}1045.2(1.03) \\
1138.8(1.03) \\
1130.9(1.03) \\
1179.6(1.03)\end{array}$ & $\begin{array}{c}\text { Reference } \\
8.95^{\mathrm{e}} \\
8.19 \\
12.86^{\mathrm{d}}\end{array}$ & 0.01 & $\begin{array}{l}231 \\
234 \\
238 \\
247\end{array}$ & $\begin{array}{l}1102.4(1.03) \\
1097.0(1.03) \\
1173.7(1.03) \\
1119.6(1.03)\end{array}$ & $\begin{array}{l}\text { Reference } \\
-0.49 \\
6.47 \\
1.56\end{array}$ & 0.37 \\
\hline sTNF-R2 (pg/mL) & $\begin{array}{l}232 \\
237 \\
243 \\
241\end{array}$ & $\begin{array}{l}4131.6(1.02) \\
4299.3(1.02) \\
4266.3(1.02) \\
4487.3(1.02)\end{array}$ & $\begin{array}{c}\text { Reference } \\
4.06 \\
3.26 \\
8.61^{\mathrm{e}}\end{array}$ & 0.02 & $\begin{array}{l}231 \\
235 \\
240 \\
246\end{array}$ & $\begin{array}{l}4181.0(1.02) \\
4166.1(1.02) \\
4459.7(1.02) \\
4385.1(1.02)\end{array}$ & $\begin{array}{c}\text { Reference } \\
-0.36 \\
6.67^{\mathrm{e}} \\
4.88\end{array}$ & 0.03 \\
\hline $\mathrm{IL}-1 \beta(\mathrm{pg} / \mathrm{mL})$ & $\begin{array}{l}221 \\
231 \\
224 \\
224\end{array}$ & $\begin{array}{l}1.13(1.08) \\
1.29(1.08) \\
1.26(1.08) \\
1.34(1.08)\end{array}$ & $\begin{array}{c}\text { Reference } \\
14.16 \\
11.50 \\
18.58\end{array}$ & 0.22 & $\begin{array}{l}226 \\
228 \\
217 \\
228\end{array}$ & $\begin{array}{l}1.29(1.08) \\
1.23(1.08) \\
1.18(1.08) \\
1.31(1.08)\end{array}$ & $\begin{array}{l}\text { Reference } \\
-4.65 \\
-8.53 \\
1.55\end{array}$ & 0.99 \\
\hline IL-6 (pg/mL) & $\begin{array}{l}224 \\
236 \\
236 \\
235\end{array}$ & $\begin{array}{l}3.04(1.08) \\
3.46(1.08) \\
4.01(1.08) \\
4.62(1.08)\end{array}$ & $\begin{array}{l}\text { Reference } \\
13.82^{\mathrm{d}} \\
31.91 \\
51.97^{\mathrm{e}}\end{array}$ & 0.0002 & $\begin{array}{l}226 \\
231 \\
229 \\
244\end{array}$ & $\begin{array}{l}3.53(1.08) \\
3.62(1.08) \\
3.66(1.08) \\
4.15(1.08)\end{array}$ & $\begin{array}{c}\text { Reference } \\
2.55 \\
3.68 \\
17.56\end{array}$ & 0.15 \\
\hline sGP130 (pg/mL) & $\begin{array}{l}230 \\
236 \\
240 \\
239\end{array}$ & $\begin{array}{l}175093.5(1.02) \\
179182.0(1.02) \\
180263.3(1.02) \\
181472.4(1.02)\end{array}$ & $\begin{array}{c}\text { Reference } \\
2.34 \\
2.95 \\
3.64\end{array}$ & 0.24 & $\begin{array}{l}229 \\
234 \\
239 \\
242\end{array}$ & $\begin{array}{l}177764.7(1.02) \\
175102.9(1.02) \\
183202.0(1.02) \\
180077.4(1.02)\end{array}$ & $\begin{array}{c}\text { Reference } \\
-1.50 \\
3.06 \\
1.30\end{array}$ & 0.33 \\
\hline sIL-6R (pg/mL) & $\begin{array}{l}231 \\
237 \\
241 \\
239\end{array}$ & $\begin{array}{l}21401.7(1.03) \\
21518.6(1.03) \\
22135.8(1.03) \\
21375.4(1.03)\end{array}$ & $\begin{array}{c}\text { Reference } \\
0.55 \\
3.43 \\
-0.12\end{array}$ & 0.88 & $\begin{array}{l}230 \\
234 \\
239 \\
244\end{array}$ & $\begin{array}{l}22010.4(1.03) \\
21255.1(1.03) \\
21793.7(1.03) \\
21452.7(1.03)\end{array}$ & $\begin{array}{l}\text { Reference } \\
-3.43 \\
-0.98 \\
-2.53\end{array}$ & 0.73 \\
\hline F2-IsoPs (ng/mg) & $\begin{array}{l}224 \\
228 \\
232 \\
220\end{array}$ & $\begin{array}{l}1.57(1.04) \\
1.47(1.03) \\
1.60(1.03) \\
1.54(1.04)\end{array}$ & $\begin{array}{l}\text { Reference } \\
-6.37 \\
1.91 \\
-1.91\end{array}$ & 0.88 & $\begin{array}{l}230 \\
233 \\
214 \\
226\end{array}$ & $\begin{array}{l}1.50(1.03) \\
1.50(1.03) \\
1.63(1.04) \\
1.56(1.04)\end{array}$ & $\begin{array}{c}\text { Reference } \\
0.00 \\
8.67 \\
4.00\end{array}$ & 0.2 \\
\hline F2-IsoP-M (ng/mg) & $\begin{array}{l}215 \\
221 \\
223 \\
217\end{array}$ & $\begin{array}{l}0.51(1.04) \\
0.55(1.03) \\
0.64(1.03) \\
0.65(1.04)\end{array}$ & $\begin{array}{c}\text { Reference } \\
7.84 \\
25.49^{\mathrm{d}} \\
27.45^{\mathrm{d}}\end{array}$ & $<0.0001$ & $\begin{array}{l}224 \\
226 \\
204 \\
221\end{array}$ & $\begin{array}{l}0.51(1.03) \\
0.58(1.03) \\
0.63(1.03) \\
0.62(1.03)\end{array}$ & $\begin{array}{c}\text { Reference } \\
13.73^{\mathrm{d}} \\
23.53^{\mathrm{d}} \\
21.57^{\mathrm{d}}\end{array}$ & $<0.0001$ \\
\hline
\end{tabular}

${ }^{a}$ Adjusted for age, education, occupation, cigarette smoking, alcohol consumption, physical activity, menopausal status, regular use of vitamin supplements, regular use of aspirin or other non-steroidal anti-inflammatory drugs, total fruit and vegetable intake, total energy intake, Charlson comobidity index, other infectious or inflammation-related diseases, use of antibiotics and vitamin supplements in the week before sample collection, and assay batch using general linear models. ${ }^{\mathrm{b}}$ Quartile cutoffs for waist-to-height ratio: $0.47,0.51$, and 0.56 ; quartile cutoffs for waistto-hip ratio: $0.79,0.82$, and 0.86 . ${ }^{\mathrm{C}}$ Difference $(\%)=$ (geometric mean of inflammatory marker for each quartile - geometric mean for the lowest quartile)/geometric mean for the lowest quartile of body mass index or waist circumference. ${ }^{\mathrm{d}} p<0.01{ }^{\mathrm{e}} p<0.05$. CRP: C-reactive protein; $\mathrm{F}_{2}$ IsoPs: $15-\mathrm{F}_{2 t}$-isoprostanes; $\mathrm{F}_{2}$-IsoP-M: 2,3-dinor-5,6-dihydro-15- $\mathrm{F}_{2 t}$-isoprostanes; IL-1 $\beta$ : interleukin $1 \beta$; IL-6: interleukin 6; sGP130: soluble GP130; sIL-6R: soluble IL-6 receptor; sTNF-R1: soluble tumor necrosis factor receptor 1; sTNF-R2: soluble tumor necrosis factor receptor 2; TNF- $\alpha$ : tumor necrosis factor $\alpha$. 
Supplemental Table 3

Multivariable-adjusted concentrations of inflammatory and oxidative stress markers in women according to quartile of body mass index or waist-to-hip ratio with mutual adjustment for both anthropometric measures ${ }^{\mathrm{a}}$

\begin{tabular}{|c|c|c|c|c|c|c|c|c|}
\hline \multirow[t]{2}{*}{ Markers } & \multicolumn{4}{|c|}{ By quartile of BMI, after additional adjustment for $\mathrm{WHR}^{\mathrm{b}}$} & \multicolumn{4}{|c|}{ By quartile of WHR, after additional adjustment for $\mathrm{BMI}^{\mathrm{b}}$} \\
\hline & $n$ & $\begin{array}{c}\text { Geometric } \\
\text { mean }(\mathrm{SEE})\end{array}$ & $\begin{array}{c}\text { Difference } \\
(\%)^{\mathrm{c}}\end{array}$ & $\begin{array}{l}P \text { for } \\
\text { trend }\end{array}$ & $n$ & $\begin{array}{c}\text { Geometric } \\
\text { mean }(\mathrm{SEE})\end{array}$ & $\begin{array}{c}\text { Difference } \\
(\%)^{\mathrm{c}}\end{array}$ & $\begin{array}{l}P \text { for } \\
\text { trend }\end{array}$ \\
\hline $\mathrm{CRP}(\mathrm{mg} / \mathrm{L})$ & $\begin{array}{l}171 \\
200 \\
209 \\
210\end{array}$ & $\begin{array}{l}0.86(1.09) \\
1.08(1.08) \\
1.29(1.08) \\
1.58(1.08)\end{array}$ & $\begin{array}{c}\text { Reference } \\
25.58^{\mathrm{d}} \\
50.00^{\mathrm{e}} \\
83.72^{\mathrm{e}}\end{array}$ & $<0.0001$ & $\begin{array}{l}185 \\
206 \\
195 \\
204\end{array}$ & $\begin{array}{l}0.94(1.08) \\
1.05(1.08) \\
1.30(1.08) \\
1.55(1.08)\end{array}$ & $\begin{array}{c}\text { Reference } \\
11.7 \\
38.30^{\mathrm{e}} \\
64.89^{\mathrm{e}}\end{array}$ & $<0.0001$ \\
\hline TNF- $\alpha(\mathrm{pg} / \mathrm{mL})$ & $\begin{array}{l}247 \\
250 \\
252 \\
248\end{array}$ & $\begin{array}{l}5.36(1.05) \\
5.39(1.05) \\
6.29(1.05) \\
6.75(1.05)\end{array}$ & $\begin{array}{c}\text { Reference } \\
0.56 \\
17.35^{\mathrm{d}} \\
25.93^{\mathrm{e}}\end{array}$ & 0.0002 & $\begin{array}{l}250 \\
247 \\
245 \\
255\end{array}$ & $\begin{array}{l}5.70(1.05) \\
5.75(1.05) \\
5.88(1.05) \\
6.35(1.05)\end{array}$ & $\begin{array}{c}\text { Reference } \\
0.88 \\
3.16 \\
11.40\end{array}$ & 0.12 \\
\hline sTNF-R1 (pg/mL) & $\begin{array}{l}233 \\
240 \\
233 \\
244\end{array}$ & $\begin{array}{l}1095.5(1.03) \\
1072.5(1.03) \\
1128.6(1.03) \\
1197.4(1.03)\end{array}$ & $\begin{array}{c}\text { Reference } \\
-2.10 \\
3.02 \\
9.30^{\mathrm{d}}\end{array}$ & 0.018 & $\begin{array}{l}231 \\
234 \\
238 \\
247\end{array}$ & $\begin{array}{l}1124.5(1.03) \\
1104.0(1.03) \\
1164.1(1.03) \\
1101.0(1.03)\end{array}$ & $\begin{array}{c}\text { Reference } \\
-1.82 \\
3.52 \\
-2.08\end{array}$ & 0.93 \\
\hline sTNF-R2 (pg/mL) & $\begin{array}{l}233 \\
240 \\
235 \\
244\end{array}$ & $\begin{array}{l}4290.0(1.02) \\
4220.1(1.02) \\
4215.3(1.02) \\
4468.4(1.02)\end{array}$ & $\begin{array}{c}\text { Reference } \\
-1.63 \\
-1.74 \\
4.16\end{array}$ & 0.22 & $\begin{array}{l}231 \\
235 \\
240 \\
246\end{array}$ & $\begin{array}{l}4228.3(1.02) \\
4181.1(1.02) \\
4439.1(1.02) \\
4343.7(1.02)\end{array}$ & $\begin{array}{c}\text { Reference } \\
-1.12 \\
4.99 \\
2.73\end{array}$ & 0.17 \\
\hline $\mathrm{IL}-1 \beta(\mathrm{pg} / \mathrm{mL})$ & $\begin{array}{l}226 \\
224 \\
225 \\
224\end{array}$ & $\begin{array}{l}1.16(1.08) \\
1.15(1.08) \\
1.25(1.08) \\
1.48(1.08)\end{array}$ & $\begin{array}{c}\text { Reference } \\
-0.86 \\
7.76 \\
27.59^{\mathrm{d}}\end{array}$ & 0.03 & $\begin{array}{l}226 \\
228 \\
217 \\
228\end{array}$ & $\begin{array}{l}1.35(1.08) \\
1.24(1.08) \\
1.16(1.08) \\
1.26(1.08)\end{array}$ & $\begin{array}{c}\text { Reference } \\
-8.15 \\
-14.07 \\
-6.67\end{array}$ & 0.51 \\
\hline IL-6 (pg/mL) & $\begin{array}{l}223 \\
232 \\
244 \\
231\end{array}$ & $\begin{array}{l}3.41(1.08) \\
3.15(1.08) \\
3.71(1.08) \\
4.91(1.08)\end{array}$ & $\begin{array}{c}\text { Reference } \\
-7.62 \\
8.80 \\
43.99^{\mathrm{e}}\end{array}$ & 0.001 & $\begin{array}{l}226 \\
231 \\
229 \\
244\end{array}$ & $\begin{array}{l}3.83(1.08) \\
3.72(1.08) \\
3.53(1.08) \\
3.89(1.08)\end{array}$ & $\begin{array}{c}\text { Reference } \\
-2.87 \\
-7.83 \\
1.57\end{array}$ & 1 \\
\hline sGP130 (pg/mL) & $\begin{array}{l}230 \\
239 \\
231 \\
244\end{array}$ & $\begin{array}{l}179935.2(1.02) \\
176590.7(1.02) \\
180963.7(1.02) \\
178839.5(1.02)\end{array}$ & $\begin{array}{c}\text { Reference } \\
-1.86 \\
0.57 \\
-0.61\end{array}$ & 0.93 & $\begin{array}{l}229 \\
234 \\
239 \\
242\end{array}$ & $\begin{array}{l}178189.9(1.02) \\
175242.0(1.02) \\
183020.5(1.02) \\
179708.8(1.02)\end{array}$ & $\begin{array}{c}\text { Reference } \\
-1.65 \\
2.71 \\
0.85\end{array}$ & 0.46 \\
\hline sIL-6R (pg/mL) & $\begin{array}{l}232 \\
240 \\
232 \\
243\end{array}$ & $\begin{array}{l}20539.7(1.03) \\
21733.4(1.03) \\
21784.2(1.03) \\
22438.5(1.03)\end{array}$ & $\begin{array}{c}\text { Reference } \\
5.81 \\
6.06 \\
9.24\end{array}$ & 0.10 & $\begin{array}{l}230 \\
234 \\
239 \\
244\end{array}$ & $\begin{array}{l}22281.7(1.03) \\
21339.7(1.03) \\
21683.8(1.03) \\
21230.6(1.03)\end{array}$ & $\begin{array}{l}\text { Reference } \\
-4.23 \\
-2.68 \\
-4.72\end{array}$ & 0.42 \\
\hline F2-IsoPs (ng/mg) & $\begin{array}{l}219 \\
226 \\
232 \\
226\end{array}$ & $\begin{array}{l}1.65(1.04) \\
1.48(1.03) \\
1.54(1.03) \\
1.53(1.04)\end{array}$ & $\begin{array}{l}\text { Reference } \\
-10.30^{\mathrm{d}} \\
-6.67 \\
-7.27\end{array}$ & 0.29 & $\begin{array}{l}230 \\
233 \\
214 \\
226\end{array}$ & $\begin{array}{l}1.48(1.04) \\
1.49(1.03) \\
1.65(1.04) \\
1.58(1.04)\end{array}$ & $\begin{array}{c}\text { Reference } \\
0.68 \\
11.49^{\mathrm{d}} \\
6.76\end{array}$ & 0.08 \\
\hline F2-IsoP-M (ng/mg) & $\begin{array}{l}213 \\
218 \\
223 \\
221\end{array}$ & $\begin{array}{l}0.56(1.04) \\
0.55(1.03) \\
0.59(1.03) \\
0.63(1.03)\end{array}$ & $\begin{array}{c}\text { Reference } \\
-1.79 \\
5.36 \\
12.50^{\mathrm{d}}\end{array}$ & 0.01 & $\begin{array}{l}224 \\
226 \\
204 \\
221\end{array}$ & $\begin{array}{l}0.52(1.03) \\
0.58(1.03) \\
0.62(1.03) \\
0.61(1.03)\end{array}$ & $\begin{array}{c}\text { Reference } \\
11.54^{\mathrm{d}} \\
19.23^{\mathrm{e}} \\
17.31^{\mathrm{e}}\end{array}$ & 0.001 \\
\hline
\end{tabular}

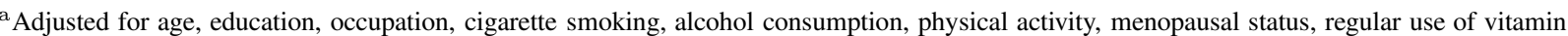
supplements, regular use of aspirin or other non-steroidal anti-inflammatory drugs, total fruit and vegetable intake, total energy intake, Charlson comobidity index, other infectious or inflammation-related diseases, use of antibiotics and vitamin supplements in the week before sample collection, and assay batch using general linear models. ${ }^{\mathrm{b}}$ Quartile cutoffs for body mass index: $22.3,24.4$, and $26.7 \mathrm{~kg} / \mathrm{m}^{2}$; quartile cutoffs for waist-to-hip ratio: $0.79,0.82$, and $0.86 .{ }^{\mathrm{c}}$ Difference $(\%)=$ (geometric mean of inflammatory marker for each quartile - geometric mean for the lowest quartile)/geometric mean for the lowest quartile of body mass index or waist-to-hip ratio. ${ }^{\mathrm{d}} p<0.05$. ${ }^{\mathrm{e}} p<0.01$. CRP: Creactive protein; $\mathrm{F}_{2}$-IsoPs: $15-\mathrm{F}_{2} t$-isoprostanes; $\mathrm{F}_{2}$-IsoP-M: 2,3-dinor-5,6-dihydro-15-F $2 t$-isoprostanes; IL-1 $\beta$ : interleukin $1 \beta$; IL-6: interleukin 6; sGP130: soluble GP130; sIL-6R: soluble IL-6 receptor; sTNF-R1: soluble tumor necrosis factor receptor 1; sTNF-R2: soluble tumor necrosis factor receptor 2; TNF- $\alpha$ : tumor necrosis factor $\alpha$. 


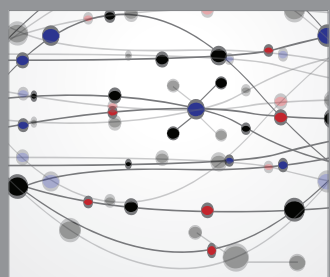

The Scientific World Journal
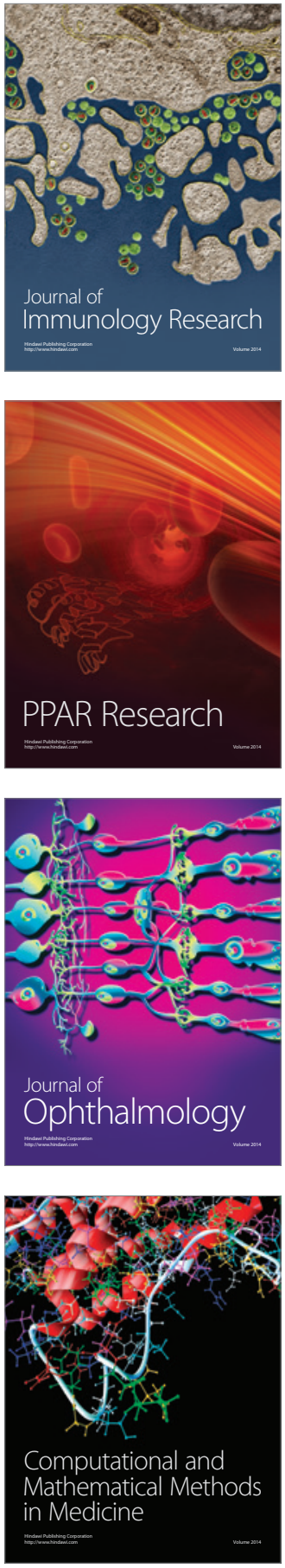

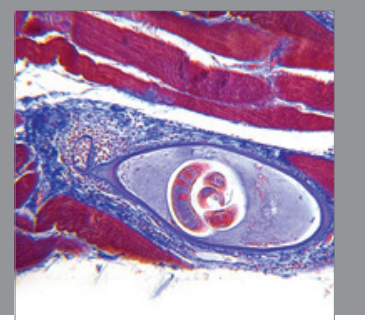

Gastroenterology

Research and Practice
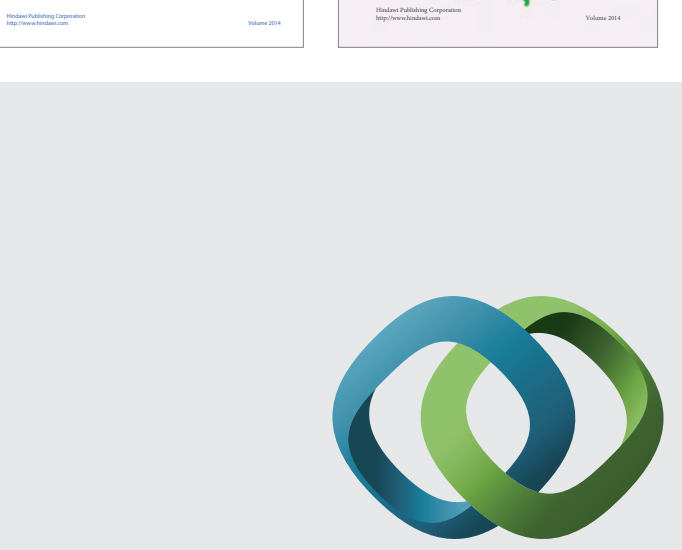

\section{Hindawi}

Submit your manuscripts at

http://www.hindawi.com
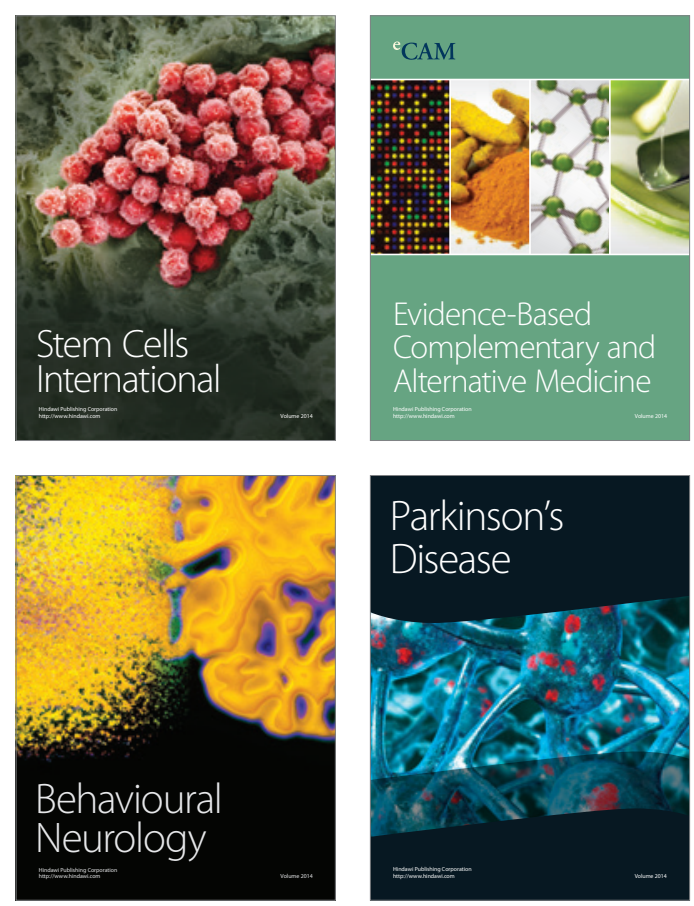

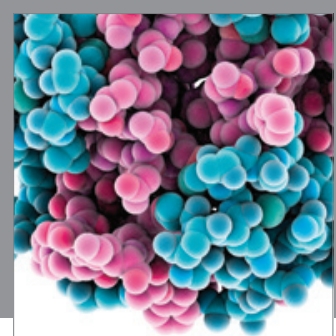

Journal of
Diabetes Research

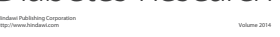

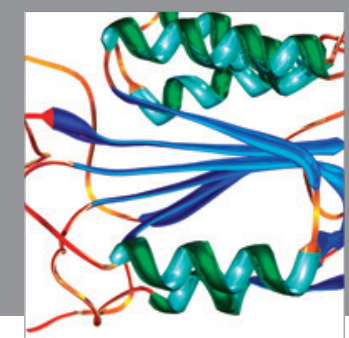

Disease Markers
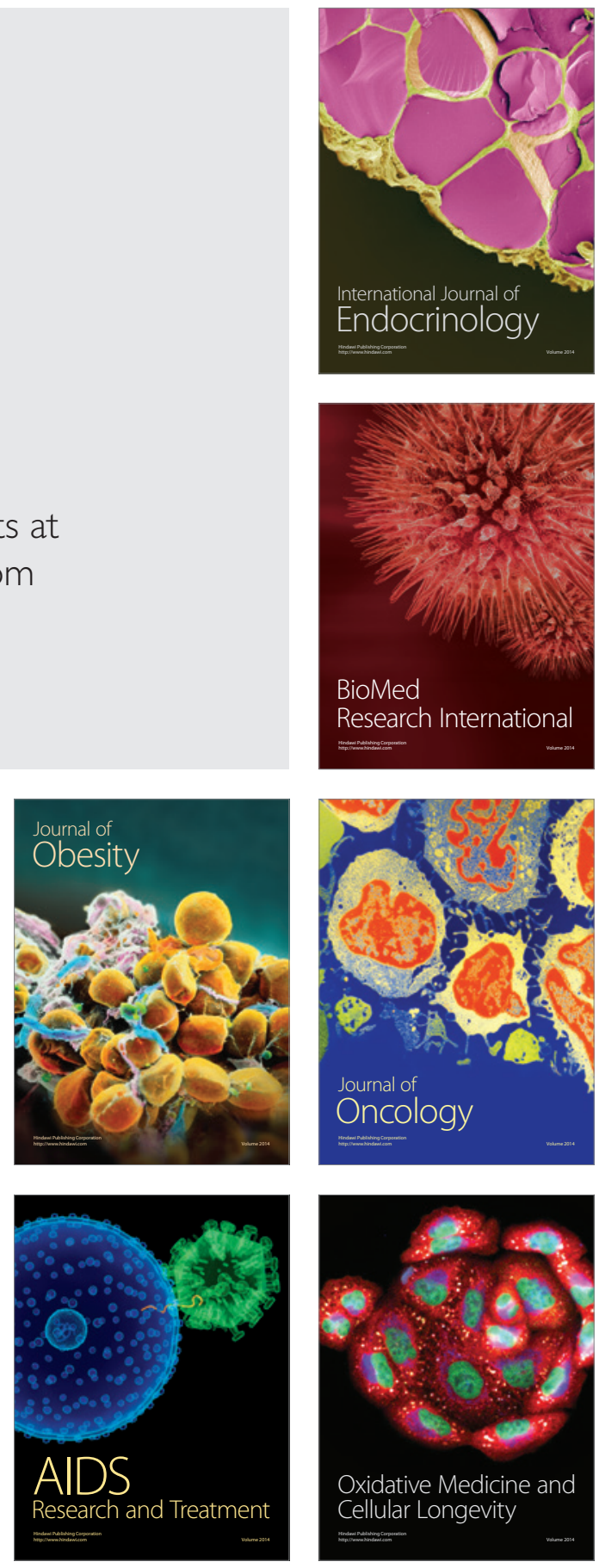